\title{
Fine scale sediment structure and geochemical signature between eastern and western North Atlantic during Heinrich events 1 and 2
}

\author{
H. Rashid ${ }^{\mathrm{a}, *}$, F. Saint-Ange ${ }^{\mathrm{b}, \mathrm{e}}$, D.C. Barber ${ }^{\mathrm{c}}$, M.E. Smith ${ }^{\mathrm{a}}$, N. Devalia ${ }^{\mathrm{d}}$ \\ ${ }^{a}$ Byrd Polar Research Center, Ohio State University, Columbus, OH, USA \\ ${ }^{\mathrm{b}}$ Geological Survey of Canada (Atlantic), Bedford Institute of Oceanography, P.O. Box 1006, Dartmouth, Nova Scotia B2Y 4A2, Canada \\ ${ }^{\mathrm{c}}$ Department of Geology, Bryn Mawr College, Bryn Mawr, PA, USA \\ ${ }^{\mathrm{d}}$ Department of Biology, McGill University, Montréal, Québec, Canada \\ ${ }^{\mathrm{e}}$ Department of Oceanography, Dalhousie University, Halifax, Nova Scotia, Canada
}

\section{A R T I C L E I N F O}

\section{Article history:}

Received 24 May 2011

Received in revised form

2 April 2012

Accepted 30 April 2012

Available online 15 June 2012

\section{Keywords:}

Heinrich iceberg-rafting

Radiogenic isotopes

Cumberland sound ice-shelf

Hudson Strait ice-stream

Trinity Trough ice-stream

\begin{abstract}
A B S T R A C T
Heinrich iceberg-rafting events 1 and $2(\mathrm{H} 1$ and $\mathrm{H} 2)$ in the Labrador Sea are identified by their typical nepheloid-flow deposit sedimentary structure, high bulk carbonate, increase in iceberg-rafted detritus (IRD), and depletion of $\delta^{18} \mathrm{O}$ in the surface-dwelling foraminifer, Neogloboquadrina pachyderma (s). $\mathrm{H}$-layers in this region have sedimentological characteristics different than those in the North Atlantic, and consist of IRD interspersed in pelagic sediments. High resolution ${ }^{14} \mathrm{C}$-AMS dates allowed us to delineate the leads and lags in instability between different ice-streams of the former Laurentide icesheet (LIS). Our data suggest that the discharge from the Hudson Strait ice-stream was followed by Cumberland Sound ice-sheet during $\mathrm{H} 1$ and $\mathrm{H} 2$. New radiogenic isotopes from the ice-proximal and surficial sediments of the greater Hudson Strait region and Labrador Sea HO, H1 and H2 layers suggest that carbonate-rich layers were only derived from Hudson Strait, not Baffin Bay.

Fine scale structure of $\mathrm{H} 1$ and $\mathrm{H} 2$ intervals in Labrador Sea slope cores is characterized by two lithic peaks dominated by detrital carbonate grains and a single peak in cores from the central Labrador Sea. A similar pattern in the structure of $\mathrm{H} 1$ and $\mathrm{H} 2$ is observed along the western European margin. These findings contrast with North Atlantic $\mathrm{H} 1$ and $\mathrm{H} 2$ intervals, which are characterized by a peak of carbonate-rich grains, followed by a peak of quartz and volcanic grains. This comparison with North Atlantic and western European margin cores leads us to suggest that the coupling or lack thereof, between the LIS and European ice-sheet, is related to the depositional processes occurring along the margins, as well as the distance from the sources and the ability of the oceanic currents to disperse icebergs. Any significant change in ice-sheet dynamics would be recorded close to the ice-sheet margin, while distal locations would only record extreme events. We hypothesize that the discordance between the findings reported in the literature is most likely similar to the difference between the upper slope/ deep Labrador sites and the Flemish Pass site described in this contribution but requires vigorous testing. Crown Copyright $\odot 2012$ Published by Elsevier Ltd. All rights reserved.
\end{abstract}

\section{Introduction}

Sediment cores between $40^{\circ}$ and $55^{\circ} \mathrm{N}$ from the North Atlantic Ocean contain a series of distinct IRD-rich layers corresponding to Heinrich layers (H-layers) derived from the LIS during the last glacial period (70-10 ka) (Heinrich, 1988; Bond et al., 1993; Hodell and Curtis, 2008; Rashid and Boyle, 2008; Stein et al., 2009). In the North Atlantic, these H-layers are identified by a sudden increase in the coarse lithic fraction $(\%>150 \mu \mathrm{m})$, a near absence of foraminifera, dominance of the polar planktonic foraminifera

\footnotetext{
* Corresponding author. Tel.: +1 614292 5040; fax: +1 6142924697.

E-mail address: rashid.29@osu.edu (H. Rashid).
}

Neogloboquadrina pachyderma (s), and a lowering of inferred seasurface salinity (Heinrich, 1988; Bond et al., 1993; Cortijo et al., 2005). The presence of detrital carbonate grains within the IRDlayers and the geochemical signature of the non-carbonate fraction suggest that the LIS was the main source of icebergs during the H-events (Bond and Lotti, 1995; Grousset et al., 2001; Peck et al., 2008; Haapaniemi et al., 2010). In contrast, the lack of detrital carbonate grains within the other IRD-layers suggests that the icebergs were supplied by the European ice-sheet (EIS); namely, the Icelandic, Scandinavian, British, and East Greenlandic icesheets. These IRD-layers are commonly known as the low amplitude Dansgaard-Oeschger (D/O) iceberg-rafting events (Bond and Lotti, 1995). In contrast to the North Atlantic, H-layers in the Labrador Sea are identified by their distinctive nepheloid-flow deposit 
sedimentary structure, high bulk carbonate, increases in the coarse fraction, and depletion of $\delta^{18} \mathrm{O}$ in $N$. pachyderma (s) (Andrews and Tedesco, 1992; Hillaire-Marcel et al., 1994; Hesse and Khodabakhsh, 1998; Rashid et al., 2003a). The D/O iceberg-rafting events in the North Atlantic have been a topic of research for the last decade (Bond et al., 1999; Peck et al., 2008; Scourse et al., 2009; Haapaniemi et al., 2010). However, it is noteworthy that these events are not found in the Labrador Sea (see Andrews and Barber, 2002).

The discovery of H-events (Heinrich, 1988) led to many modeling studies devoted to understanding their environmental implications, not only for the circum-North Atlantic region but for the global climate (Stouffer et al., 2006; Liu et al., 2009; Timmermann and Menviel, 2009; Brady and Otto-Bliesner, 2010). The climatic implications of the H-events in the North Atlantic are widespread cooling and reduction in sea surface salinity (1-3\%) (Cortijo et al., 1997, 2005; Benway et al., 2010). Freshwater released from the Hudson Strait and St. Lawrence ice-streams (Shaw et al., 2006), in addition to freshwater emanating from iceberg-rafting, are presumed to form a freshwater cap in the North Atlantic. This freshwater cap may have prevented the North Atlantic Current, the northern extension of the Gulf Stream, from reaching the Greenland-Iceland-Norwegian seas, which in turn may have weakened the Atlantic meridional ocean circulation (AMOC) (Rahmstorf, 1994; Stouffer et al., 2006; Dickson et al., 2008; Renold et al., 2010; Cheng et al., 2011; Guihou et al., 2011). After the ice sheet had thinned sufficiently at the end of an H-event, rapid iceberg calving stopped and the previous ocean circulation mode resumed, causing the climate to warm rapidly (Seidov and Haupt, 2003; Kageyama et al., 2009). The extent to which H-events perturbed the AMOC has never been demonstrated unambiguously by the proxy records (Lynch-Stieglitz et al., 2007; Cheng et al., 2011).

Delineating the extent and thickness of the LIS has been a topic of research for many decades. However, it is often assumed that the LIS was geographically centered over Hudson Bay during the late Pleistocene (Dyke and Prest, 1987; Dyke et al., 2002; Peltier, 2004; Clark et al., 2009). As a result of its great height, the LIS significantly modified atmospheric circulation and thus influenced climatic and environmental conditions in the Labrador Sea and surrounding region. In any event, at the start of $\mathrm{H} 1$ and $\mathrm{H} 2$, ice-stream margins probably extended to the Labrador trough edges, if not farther offshore (Andrews and MacLean, 2003; Rashid and Piper, 2007), and there may have been a peripheral floating ice-shelf (Hulbe et al., 2004). Considerable debate exists regarding whether the Quaternary ice-sheets of the Northern Hemisphere collapsed synchronously during $\mathrm{H} 1$ and $\mathrm{H} 2$ or whether these events were the result of sequential collapses of ice-sheets (Grousset et al., 2001; Haapaniemi et al., 2010). These questions arose after analysis of the ultra-fine structure of H-layers documented IRD sourced from various Northern Hemisphere ice sheets. Some evidence has emerged as to the timing of contributions from individual ice sheets, suggesting that the initiation of $\mathrm{H} 1$ and $\mathrm{H} 2$ was not synchronous for all ice sheets (Dowdeswell et al., 1999). This finding is important in delineating the mechanism of initiation of H-events.

In this study, we use a series of high accumulation rate sediment cores from the Labrador Sea covering the latitudinal transect between $62.41^{\circ}$ and $47.74^{\circ} \mathrm{N}$, allowing us to document the icemargin and ice-stream processes during $\mathrm{H} 1$ and $\mathrm{H} 2$. We have also used the high-resolution published records from the North Atlantic and European ice-sheet margin to provide a circum-North Atlantic perspective. By so doing, we investigate (1) the fine-scale structure of $\mathrm{H} 1$ and $\mathrm{H} 2$ from the Labrador Sea; (2) examine leads and lags in ice-stream and ice-shelf response among Cumberland Sound, Hudson Strait, and Trinity Trough; (3) establish a spatial correlation of $\mathrm{H} 1$ and $\mathrm{H} 2$ layers from the ice-sheet margin proximal setting to those of the distal North Atlantic; and finally, (4) advance a conceptual model incorporating various ice-sheet margin processes occurring in both the eastern and western sides of the North Atlantic.

\section{Materials and methods}

Five cores were selected from the Labrador Sea to illustrate the main points of this study. Cores Hu9013-26, Hu97048-07, Hu97048-16, and MD99-2233 (hereafter Hu90-26, Hu97-07, Hu9716, and MD99-33) were retrieved from the SE Baffin Slope, Labrador Slope, and Rise seaward of Hudson Strait (Fig. 1). For the southern Labrador Sea, we have chosen core Pa96018-06 (hereafter Pa96-06) which was collected from central Flemish Pass. These sites provide a wide latitudinal spread covering a region that includes two icestreams (i.e., Hudson Strait and Trinity Trough) and one ice-shelf (i.e., Cumberland Sound) in the eastern sector of the LIS. We have also used three published records from cores SU90-09 (Grousset et al., 2001), MD95-2002 (Zaragosi et al., 2001) and SU81-18 (Bard et al., 2000) from the central and eastern North Atlantic, respectively (Table 1 ). The latter two records provide a latitudinal coverage of various ice-streams discharge of the EIS from $47^{\circ} 27.12$ to $37^{\circ} .46 \mathrm{~N}$.

Of all the cores used in this study from the Labrador Sea, physical properties (density, velocity and magnetic susceptibility) data were determined only from cores Pa96-06 and MD99-33. These data were acquired by using a MultiSensor Core Logger (MSCL) at a $2 \mathrm{~cm}$ interval (Rashid, 2002).

To decipher the internal sedimentary structures, X-radiographs were made from 1-cm thick sediment slabs (Rashid et al., 2003a). Cores were subsampled at $2.5-5 \mathrm{~cm}$ intervals with $10-25 \mathrm{~cm}^{3}$ plastic vials, and dried in an oven at $63{ }^{\circ} \mathrm{C}$ for $24 \mathrm{~h}$. Bulk carbon content, carbonate, and total organic carbon were analyzed from $0.5 \mathrm{~g}$ of dry sediment using a LECO CS-125 infrared analyzer. Inorganic carbonate content was calculated as if all carbonate were $\mathrm{CaCO}_{3}$ and is reported as $\mathrm{CaCO}_{3}(\%)$ using the equation, $\mathrm{CaCO}_{3}$ $(\%)=($ inorganic carbon $/ 12) \times 100$. The remaining sample was washed through a $63 \mu \mathrm{m}$ sieve. The $>150 \mu \mathrm{m}$ fraction was used to pick foraminifera, and the weights of foraminifera and lithic grains from this fraction were recorded. IRD is defined as sediment coarser than $150 \mu \mathrm{m}$ (Rashid et al., 2003a; Rashid and Piper, 2007).

Stable oxygen isotopes $\left(\delta^{18} \mathrm{O}\right)$ were determined using handpicked N. pachyderma (s) (Nps) specimens from the 150-250 $\mu \mathrm{m}$ size fraction. We have determined $\delta^{18} \mathrm{O}$ using the isotope ratio mass spectrometer (IRMS) in the GEOTOP (Université de Québec à Montréal), School of Earth Sciences (Ohio State University), and Keck Paleoenvironmental \& Environmental Stable Isotope Laboratory (University of Kansas). The overall analytical reproducibility, as determined from replicate measurements on the standard material, is routinely better than $\pm 0.05 \%$ o $( \pm 1 \sigma)$ for both $\delta^{18} \mathrm{O}$ and $\delta^{13} \mathrm{C}$ (see Rashid et al., 2003a, 2011; for detailed description). For several cores, and especially core MD99-33, lack of adequate $N$. pachyderma (s) prevented us from constructing a complete oxygen isotope stratigraphy.

Radiogenic isotopic ratios of $\mathrm{Sr}$ and $\mathrm{Nd}$ as well as elemental abundances of $\mathrm{Rb}, \mathrm{Sr}, \mathrm{Sm}$, and Nd were analyzed in the siliciclastic component ( $<63 \mu \mathrm{m}$ size fraction) for the H0 and $\mathrm{H} 2$ from cores Hu97-07 and Hu91045-94 (Orphan Knoll) (Barber, 2001; Farmer et al., 2003). The isotopic ratios of ${ }^{143} \mathrm{Nd} /{ }^{144} \mathrm{Nd}$ are generally expressed in the usual $\varepsilon_{\mathrm{Nd}}$ notation, where

$\varepsilon_{\mathrm{Nd}_{(0)}}=\left[\frac{\left({ }^{143} \mathrm{Nd} /{ }^{144} \mathrm{Nd}\right) \text { sample }-\left({ }^{143} \mathrm{Nd} /{ }^{144} \mathrm{Nd}\right) \text { standard }}{\left({ }^{143} \mathrm{Nd} /{ }^{144} \mathrm{Nd}\right) \text { standard }}\right] \times 10^{4}$ 


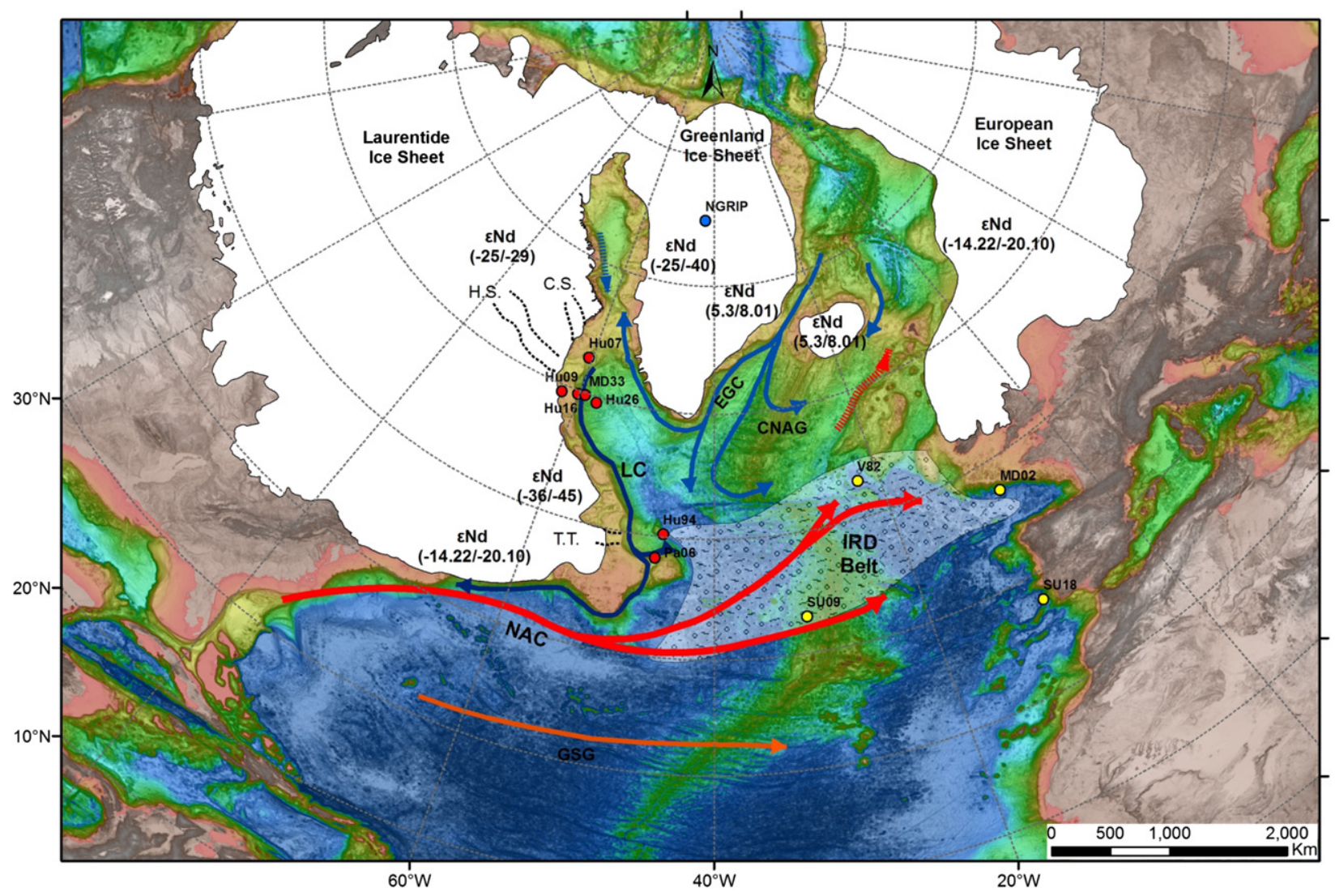

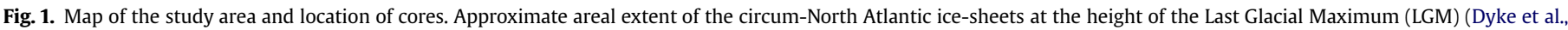

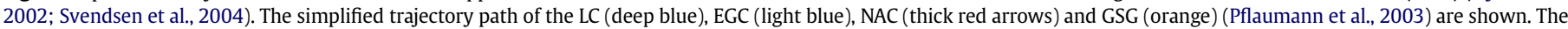

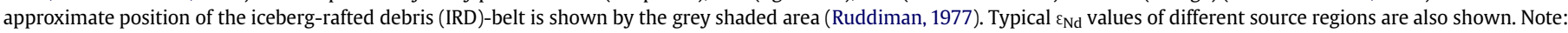

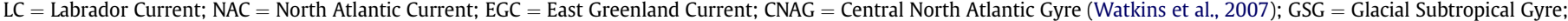

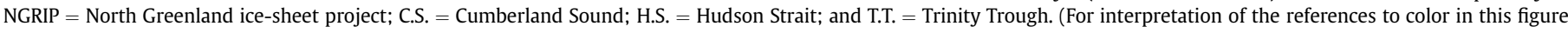
legend, the reader is referred to the web version of this article.)

The standard ${ }^{143} \mathrm{Nd} /{ }^{144} \mathrm{Nd}$ value of 0.512638 is the present-day value of Chondritic Uniform Reservoir (CHUR; Wasserburg et al., 1981).

Radiogenic isotopic data were analyzed using a Finnigan MAT 261 multicollector mass spectrometer at the University of Colorado, Boulder. Accelerator mass spectrometry ${ }^{14} \mathrm{C}\left({ }^{14} \mathrm{C}\right.$-AMS $)$ dates were acquired to constrain the stratigraphy of all cores used in this study. These ${ }^{14} \mathrm{C}$-AMS dates were obtained on the planktonic foraminifers

Table 1

Location of cores used and discussed in the study.

\begin{tabular}{|c|c|c|c|c|c|}
\hline Core ID & $\begin{array}{l}\text { Latitude } \\
\text { (N) }\end{array}$ & $\begin{array}{l}\text { Longitude } \\
\text { (W) }\end{array}$ & $\begin{array}{l}\text { Water } \\
\text { depth }(\mathrm{m})\end{array}$ & Locality & Reference \\
\hline Hu87033-09 & $62^{\circ} 30.99$ & $59^{\circ} 26.82$ & 1120 & SE Baffin Slope & $(1,2,3)$ \\
\hline V28-82 & 52.58 & 21.93 & 3974 & NE Atlantic & $(4,5)$ \\
\hline SU90-09 & $43^{\circ} 05$ & $31^{\circ} 05$ & 3375 & NW Atlantic & $\begin{array}{l}\text { Grousset } \\
\text { et al. (2001) }\end{array}$ \\
\hline Hu90013-26 & $59^{\circ} 31.34$ & $57^{\circ} 16.64$ & 2895 & Labrador Basin & $(6,7)$ \\
\hline Hu91045-94 & $50^{\circ} 12.26$ & $45^{\circ} 41.14$ & 3448 & Orphan Knoll & $(8,9)$ \\
\hline Pa96018-06 & $47^{\circ} 74.55$ & $46^{\circ} 20.31$ & 1050 & Flemish Pass & $(10)$ \\
\hline Hu97048-07 & $62^{\circ} 40.39$ & $60^{\circ} 34.39$ & 938 & Baffin Slope & (3); this study \\
\hline Hu97048-16 & $59^{\circ} 42.02$ & $60^{\circ} 14.30$ & 1085 & Hudson Strait & $(10)$ \\
\hline MD95-2002 & $47^{\circ} 27.12$ & $8^{\circ} 27.03$ & 2174 & Bay of Biscay & $\begin{array}{l}\text { Zaragosi } \\
\text { et al. (2001) }\end{array}$ \\
\hline MD99-2233 & $59^{\circ} 49.46$ & $59^{\circ} 09.35$ & 2350 & Saglek Bank & $(10)$ \\
\hline SU81-18 & $37^{\circ} 46$ & $10^{\circ} 11$ & 3135 & $\begin{array}{l}\text { Portuguese } \\
\text { margin }\end{array}$ & $\begin{array}{l}\text { Bard } \\
\text { et al. (2000) }\end{array}$ \\
\hline
\end{tabular}

${ }^{1}$ Andrews and Tedesco (1992); ${ }^{2}$ Andrews et al. (1995); ${ }^{3}$ Barber (2001); ${ }^{4}$ Hemming et al. (1998); ${ }^{5}$ McManus et al. (1998); ${ }^{6}$ Hesse and Khodabakhsh (1998); ${ }^{7}$ Rashid and Piper (2007); ${ }^{8}$ Hillaire-Marcel et al. (1994); ${ }^{9}$ Hillaire-Marcel et al. (2007);

${ }^{10}$ Rashid et al. (2003b, 2011). using the NSF Arizona-AMS, NOSAMS-WHOI, IsoTrace Radiocarbon Laboratory of the University of Toronto (currently out of operation) and Keck Carbon Cycle Laboratory of the University of California at Irvine facilities (Table 2). ${ }^{14} \mathrm{C}$-AMS ages were converted to calendar years before present (1950) using the calibration program (CALIB 6.0.1) of Reimer et al. (2009). We have used the MARINE09. ${ }^{14} \mathrm{C}$ dataset and regional reservoir age $(\Delta R)$ of 50 years for the Labrador Sea (Stuiver and Braziunas, 1993) (see section 4.1 for detailed discussion).

\section{Results}

\subsection{Core lithofacies}

Cores retrieved from Baffin Bay to the southern Labrador Sea show identical lithofacies. The downcore sediment facies consists of hemipelagic sediment with interspersed IRD, nepheloid-flow deposits and stratified diamict in core Hu97-07 (Fig. 2). Core MD99-33 (Fig. 3) shows an additional facies which corresponds to units of parallel-laminated mud turbidites. Light brown hemipelagic ooze was found at the core top whereas the downcore sediments are predominantly olive-grey mud. Nepheloid-flow deposit corresponds to a massive laminated facies characterized by a succession of thin IRD, mud and silt layers. These units usually show light brown to brown color possibly related to high carbonate content (Khodabakhsh, 1997; Rashid et al., 2003a). Nevertheless, the overall color can appear darker due to the variation in thickness of silt and IRD layers. 
Table 2

${ }^{14} \mathrm{C}$-AMS dates used in this study.

\begin{tabular}{|c|c|c|c|c|}
\hline & $\begin{array}{l}\text { Depth } \\
(\mathrm{cm})\end{array}$ & $\begin{array}{l}\text { Uncorrected } \\
{ }^{14} \mathrm{C} \text { age }(\mathrm{yr}) \\
\pm 1 \sigma \text { error }\end{array}$ & $\begin{array}{l}\text { Cal yr } \mathrm{BP}^{\mathrm{a}} \\
1 \sigma \text { age range }\end{array}$ & Reference \\
\hline \multicolumn{5}{|c|}{ Hu9013-26 } \\
\hline 1 & $1-3$ & $5850 \pm 70$ & $6148-6296$ & This study \\
\hline 2 & $51-53$ & $15,080 \pm 120$ & $17,618-17,977$ & Wang and Hesse (1996) \\
\hline 3 & $205-207$ & $19,970 \pm 240$ & $22,989-23,754$ & Wang and Hesse (1996) \\
\hline 4 & $276-278$ & $21,070 \pm 190$ & $24,399-24,892$ & Wang and Hesse (1996) \\
\hline \multicolumn{5}{|c|}{ Hu91045-94 } \\
\hline 1 & 1 & 176,070 & $1200-1338$ & Hillaire-Marcel et al. (1994) \\
\hline 2 & 70.5 & $6330 \pm 80$ & $6642-6837$ & Hillaire-Marcel et al. (1994) \\
\hline 3 & 97.5 & $7660 \pm 70$ & $7997-8147$ & Hillaire-Marcel et al. (1994) \\
\hline 4 & 106.5 & $8350 \pm 60$ & $8770-8967$ & Hillaire-Marcel et al. (1994) \\
\hline 5 & 124.5 & $8810 \pm 80$ & 9359-9515 & Hillaire-Marcel et al. (1994) \\
\hline 6 & 143 & $9360 \pm 70$ & $10,070-10,237$ & Hillaire-Marcel et al. (1994) \\
\hline 7 & 180.5 & $11,570 \pm 80$ & $12,900-13,116$ & Hillaire-Marcel et al. (1994) \\
\hline 8 & 187.5 & $11,540 \pm 70$ & $12,889-13,099$ & Hillaire-Marcel et al. (1994) \\
\hline 9 & 193 & $12,650 \pm 100$ & $13,874-14,193$ & Hillaire-Marcel et al. (1994) \\
\hline 10 & 212 & $13,460 \pm 90$ & $15,206-15,927$ & Hillaire-Marcel et al. (1994) \\
\hline 11 & 292 & $14,920 \pm 110$ & $17,429-17,858$ & Hillaire-Marcel et al. (1994) \\
\hline 12 & 329 & $17,270 \pm 130$ & $19,849-20,192$ & Hillaire-Marcel et al. (1994) \\
\hline 13 & 413 & $18,160 \pm 140$ & $20,951-21,415$ & Hillaire-Marcel et al. (1994) \\
\hline 14 & 431.5 & $24,820 \pm 230$ & $28,878-29,475$ & Hillaire-Marcel et al. (1994) \\
\hline 15 & 450.5 & $23,890 \pm 160$ & $28,037-28,423$ & Hillaire-Marcel et al. (1994) \\
\hline 16 & 459.5 & $24,490 \pm 180$ & $28,613-29,162$ & Hillaire-Marcel et al. (1994) \\
\hline 17 & 469 & $23,950 \pm 200$ & $28,049-28,479$ & Hillaire-Marcel et al. (1994) \\
\hline \multicolumn{5}{|c|}{ Hu97048-07 } \\
\hline 1 & $20-25$ & $11,045 \pm 25$ & $12,538-12,595$ & This study \\
\hline 2 & $65-70$ & $11,125 \pm 25$ & $12,568-12,633$ & This study \\
\hline 3 & $155-160$ & $12,030 \pm 35$ & $13,341-13,456$ & This study \\
\hline 4 & $209-211$ & $14,210 \pm 120$ & $16,754-16,986$ & This study \\
\hline 5 & $281-283$ & $17,170 \pm 160$ & $19,583-19,723$ & This study \\
\hline 6 & $354-357$ & $20,920 \pm 270$ & $24,103-24,827$ & This study \\
\hline 7 & $355-357$ & $20,810 \pm 60$ & $24,174-24,453$ & This study \\
\hline 8 & $574-576$ & $24,910 \pm 240$ & $28,926-29,541$ & This study \\
\hline \multicolumn{5}{|c|}{ Нu97048-16 } \\
\hline 1 & $175-176$ & $9100 \pm 40$ & $9673-9844$ & Rashid et al. (2011) \\
\hline 2 & $300-302$ & $10,150 \pm 35$ & $11,106-11,164$ & Rashid et al. (2011) \\
\hline 3 & $460-462$ & $11,830 \pm 30$ & $13,196-13,302$ & Rashid et al. (2011) \\
\hline 4 & $470-472$ & $14,620 \pm 170$ & $17,014-17,485$ & Rashid et al. (2003a) \\
\hline 5 & $558-559$ & $14,900 \pm 130$ & $17,400-17,828$ & Rashid et al. (2003a) \\
\hline 6 & $559-561$ & $14,990 \pm 45$ & $18,057-18,215$ & Rashid et al. (2011) \\
\hline 7 & $660-662$ & $17,810 \pm 60$ & $20,680-20,914$ & This study \\
\hline 8 & $750-752$ & $20,990 \pm 200$ & $24,285-24,844$ & Rashid et al. (2003a) \\
\hline 9 & $840-842$ & $21,200 \pm 110$ & $24,540-24,901$ & Rashid et al. (2003a) \\
\hline 10 & $858-859$ & $21,660 \pm 245$ & $25,006-25,709$ & Rashid et al. (2003a) \\
\hline 11 & $900-902$ & $22,800 \pm 110$ & $26,650-27,072$ & Rashid et al. (2003a) \\
\hline \multicolumn{5}{|c|}{ MD99-2233 } \\
\hline 1 & $0-2$ & $6475 \pm 20$ & $6870-6947$ & This study \\
\hline 2 & $210-212$ & $14,320 \pm 170$ & $16,795-17,127$ & Rashid et al. (2003b) \\
\hline 3 & $330-332$ & $18,600 \pm 160$ & $21,459-21,960$ & Rashid et al. (2003b) \\
\hline 4 & $380-382$ & $19,950 \pm 110$ & $23,181-23,540$ & Rashid et al. (2003b) \\
\hline \multicolumn{5}{|c|}{ PA96018-06 } \\
\hline 1 & $5-6$ & $10,445 \pm 30$ & $11,376-11,677$ & This study \\
\hline 2 & $35-36$ & $11,825 \pm 25$ & $13,195-13,296$ & This study \\
\hline 3 & $78-80$ & $13,800 \pm 55$ & $16,299-16,727$ & Rashid et al. (2003b) \\
\hline 4 & $152-154$ & $14,685 \pm 30$ & $17,153-17,474$ & This study \\
\hline 5 & $158-160$ & $15,500 \pm 55$ & $18,070-18,313$ & Rashid et al. (2003b) \\
\hline 5 & $240-242$ & $19,400 \pm 70$ & $22,377-22,675$ & This study \\
\hline 6 & $345-347$ & $21,470 \pm 70$ & $24,906-25,210$ & This study \\
\hline 7 & $365-367$ & $24,670 \pm 120$ & $28,860-29,366$ & This study \\
\hline
\end{tabular}

${ }^{\text {a }}$ All ${ }^{14} \mathrm{C}$-AMS dates were determined on $N$. pachyderma (s) (Nps) which were converted to calendar age (BP) by using Calib 6.0.1 (Reimer et al., 2009) online calibration program (see text).

\subsection{Core stratigraphy}

$52{ }^{14} \mathrm{C}$-AMS dates are used to identify and constrain the timing of stratigraphic units in the cores (Table 2). 32 dates are published (Hillaire-Marcel et al., 1994; Thomas et al., 2003; Rashid et al., 2003a,b, 2011; Rashid and Piper, 2007; Huppertz and Piper,

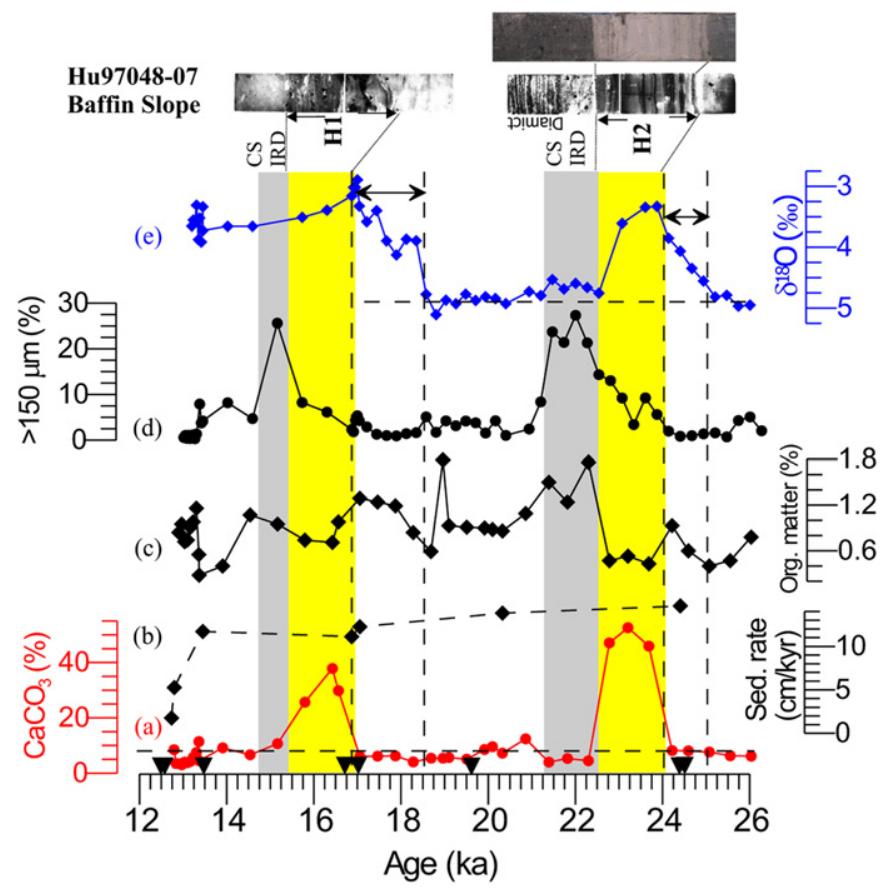

Fig. 2. Down core plots of (a) bulk carbonate as $\mathrm{CaCO}_{3}(\%)$, (b) sedimentation rate $(\mathrm{cm} /$ kyr), (c) organic matter (\%), (d) coarse fraction (\%>150 $\mu \mathrm{m})$, and (e) oxygen isotopes in N. pachyderma $(\mathrm{s})\left(\delta^{18} \mathrm{O}_{\mathrm{Nps}}\right)$ of the core Hu97048-07. X-radiographs containing $\mathrm{H} 1$ and $\mathrm{H} 2$ intervals and color core photograph containing black shale and $\mathrm{H} 2$ intervals are shown in the right hand column. Eight ${ }^{14} \mathrm{C}$-AMS dates (shown by the triangles) are converted to calendar years BP using the CALIB 6.0.1 online program (Reimer et al., 2009) and are used to constrain the age model (see text for detail). Vertical yellow bars represent $\mathrm{H} 1$ and $\mathrm{H} 2$ (Heinrich events 1 and 2 ) whereas the grey bars exhibit Cumberland Sound (CS) IRD. Two horizontal double-arrows adjacent to $\delta^{18} \mathrm{O}_{\mathrm{Nps}}$ curve (d) represent $\sim 1$ and $\sim 1.8 \mathrm{kyr}$ lead in onset of depletion in $\delta^{18} \mathrm{O}_{\mathrm{Nps}}$ before the rise of carbonate in $\mathrm{H} 2$ and $\mathrm{H} 1$, respectively. Note: Fig. S1 shows the distribution of facies and geochemical data in depth scale. (For interpretation of the references to color in this figure legend, the reader is referred to the web version of this article.)

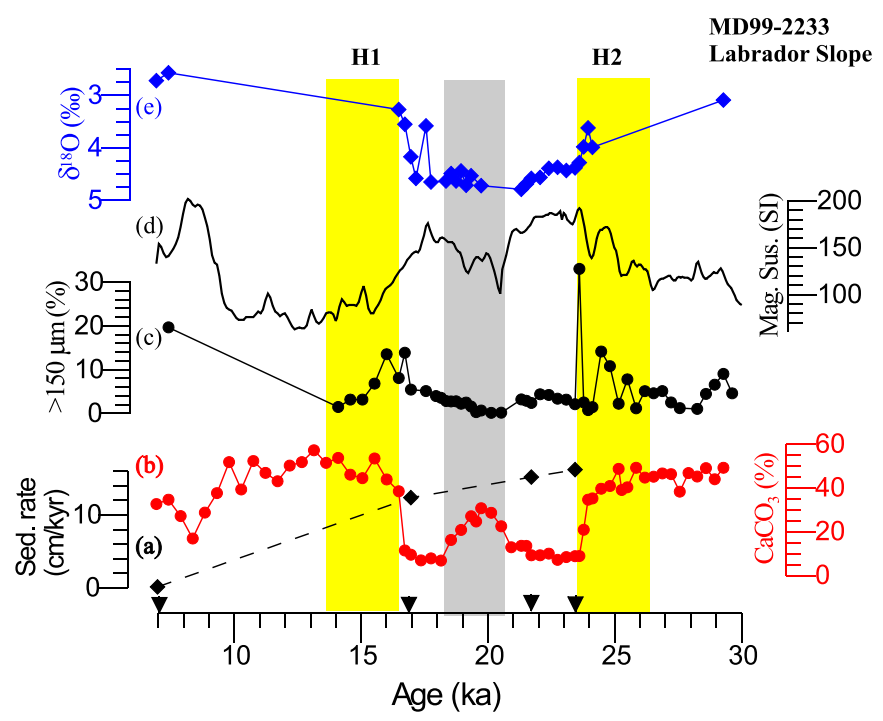

Fig. 3. Down core plots of (a) sedimentation rate ( $\mathrm{cm} / \mathrm{kyr}$ ), (b) bulk carbonate as $\mathrm{CaCO}_{3}$ (\%), (c) coarse fraction (\% $>150 \mu \mathrm{m})$, (d) magnetic susceptibility (SI unit), and (e) $\delta^{18} \mathrm{O}_{\mathrm{Nps}}$ of core MD99-2233. This core was collected at a water depth of $2350 \mathrm{~m}$ from the Labrador Slope. Four ${ }^{14} \mathrm{C}$-AMS dates (shown by the triangles) are used to constrain the age model between 7 and $25 \mathrm{ka}$. These ${ }^{14} \mathrm{C}$-AMS dates in addition to X-radiographs allowed us to confidently identify H1 and H2 (Rashid et al., 2003b). Note the grey bars represent the parallel-laminated mud-turbidites. 
2009), and 20 additional dates were obtained to further refine the age model (Figs. 2-5). This age model was constructed by linear interpolation between dates assuming a constant sedimentation rate which suggests that the cores contain a climate record at least between $\sim 7$ and $30 \mathrm{ka}$, i.e. bracketing the $\mathrm{HO}$ to $\mathrm{H} 2$ interval. Xradiographs, carbonate composition, grain size and $\delta^{18} \mathrm{O}_{\mathrm{Nps}}$ data in conjunction with ${ }^{14} \mathrm{C}$-AMS dates helped us to clearly identify $\mathrm{HO}, \mathrm{H} 1$ and $\mathrm{H} 2$.

$\mathrm{H} 1$ and $\mathrm{H} 2$ are typically $\sim 1 \mathrm{~m}$ thick in the NW Labrador Sea and $\sim 0.5 \mathrm{~m}$ thick around Flemish Pass and Orphan Knoll, indicating sedimentation rates from 4 to $15 \mathrm{~cm} / \mathrm{kyr}$. In the Saglek Bank, there is a sequence of facies in both $\mathrm{H} 1$ and $\mathrm{H} 2$, defined as units $\mathrm{A}, \mathrm{B}$ and $\mathrm{C}$ (Fig. 4) (Rashid, 2002; Rashid et al., 2003a). At the base, unit A, a carbonate rich (30-60\%) unit, overlain by unit $B$, the nepheloidflow deposit sequence, ends with unit $C$, a low-carbonate unit rich in organic matter (1-2\%). The lower boundary of $\mathrm{H} 1$ and $\mathrm{H} 2$, i.e., unit $A$, is sharp whereas unit $C$ is diffused and bioturbated (Fig. 4). In core MD22-33 (Fig. 3), finely-laminated mud turbidites topped both $\mathrm{H} 1$ and H2 (Rashid et al., 2003b; Rashid and Piper, 2007).

The H-layers show high carbonate content which are correlated to depleted $\delta^{18} \mathrm{O}_{\mathrm{Nps}}$ and usually an increase in the coarse fraction (Figs. 3-6). The SE Baffin slope core Hu97-07 shows a slightly different sequence (Figs. 2 and S1) in which the high carbonate content and depleted $\delta^{18} \mathrm{O}_{\mathrm{Nps}}$ correlates, but an increase in the coarse fraction is not tied to these changes. Furthermore, the $\delta^{18} \mathrm{O}_{\mathrm{Nps}}$ becomes depleted prior to the rise in the bulk carbonate. The increase in the coarse fraction corresponds to a drastic change in sediment color from light to dark brown, suggesting possibly a change in the sediment source.

For the central Flemish Pass core Pa96-06 (Fig. 5), we obtained six ${ }^{14} \mathrm{C}$-AMS dates to constrain the stratigraphy of upper $350 \mathrm{~cm}$ (Table 2) since the original publication of coarse-resolution data (Rashid et al., 2003b). In addition, we increased the $\delta^{18} \mathrm{O}$ data resolution within the $\mathrm{H} 1$ and $\mathrm{H} 2$ due to the accessibility to

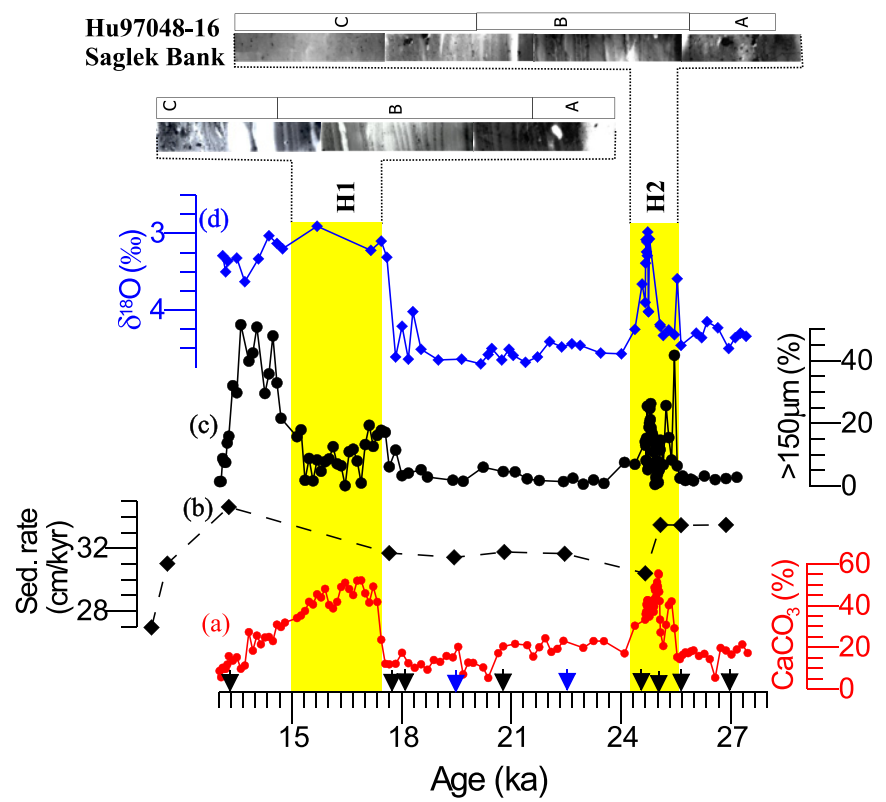

Fig. 4. Down core plots of (a) bulk carbonate as $\mathrm{CaCO}_{3}(\%)$, (b) sedimentation rate $(\mathrm{cm} /$ kyr), (c) coarse fraction $(\%>150 \mu \mathrm{m})$, and (d) $\delta^{18} \mathrm{O}$ in $N$. pachyderma (s) from core Hu97048-16. It was collected at 1085 m water depth from the slope seaward of Hudson Strait. X-radiographs containing $\mathrm{H} 1$ and $\mathrm{H} 2$ and their interpreted facies are also shown in the right hand column. Nine ${ }^{14} \mathrm{C}$-AMS dates (shown by the triangles) are converted to calendar years and are used to constrain the age model of the interval containing $\mathrm{H} 1$ and $\mathrm{H} 2$.

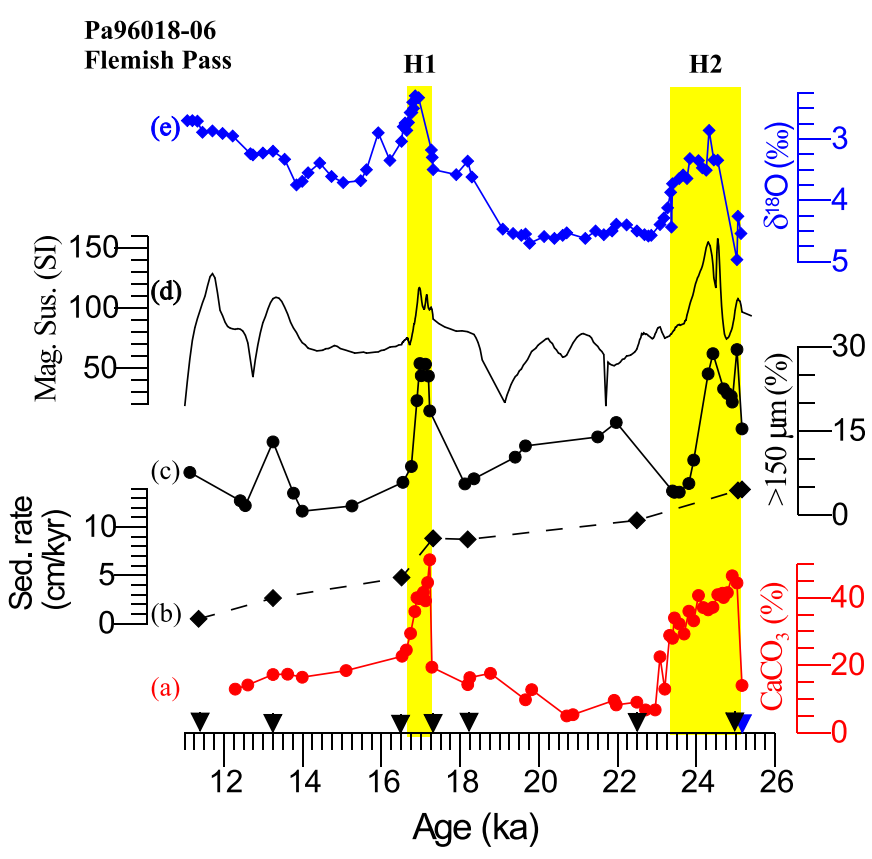

Fig. 5. (a) Bulk carbonate as $\mathrm{CaCO}_{3}$ (\%), (b) sedimentation rate $(\mathrm{cm} / \mathrm{kyr})$, (c) coarse fraction (\%>150 $\mu \mathrm{m})$, (d) magnetic susceptibility (SI unit), and (e) $\delta^{18} \mathrm{O}_{\mathrm{Nps}}$ of Flemish Pass core Pa96018-06 are plotted in age (ka) scale. Eight ${ }^{14} \mathrm{C}$-AMS dates (shown by the triangles) are used to identify $\mathrm{H} 1$ and $\mathrm{H} 2$. In addition, we have also correlated the carbonate profile with that of the Orphan Knoll core Hu91045-94 to further constrain the basal age of H2 (blue triangle) (see Fig. S2 for Hu91-94) (Stoner et al., 1998). (For interpretation of the references to color in this figure legend, the reader is referred to the web version of this article.)

a sensitive IRMS (MAT 253). As a result, we are able to determine a partial magnitude of meltwater in these events from the Flemish Pass. Two depleted $\delta^{18} \mathrm{O}$ intervals from 100 to $155 \mathrm{~cm}$ $(16.75-17.6 \mathrm{ka})$ and 280 to $345 \mathrm{~cm}(23.45-25 \mathrm{ka})$ contained $\delta^{18} \mathrm{O}$ values ranging from $2.86 \%$ o to $3.15 \%$ (Fig. 5). Enriched $\delta^{18} \mathrm{O}$ values $>4.50 \%$ were found between 160 and $260 \mathrm{~cm}$ (18.3 and $22.95 \mathrm{ka}$ ), corresponding to the last glacial maximum (LGM). One curious interval of enriched $\delta^{18} \mathrm{O}$ values between 40 and $70 \mathrm{~cm}$ (13.6 and $15.8 \mathrm{ka}$ ) was found and is consistent with the findings in cores Hu97-07, Hu97-16 and Hu91-94 (Hillaire-Marcel et al., 1994; Rashid et al., 2003a). It seems that enriched $\delta^{18} \mathrm{O}$ values are only present in the Labrador Sea and are absent in the open North Atlantic.

\subsection{Fine scale structure of $\mathrm{H} 1$ and $\mathrm{H} 2$}

Sediment composition, especially high detrital carbonate, predominantly derived from the sediments flooring the Hudson Strait (Douglas, 1970; Maclean, 1985; Andrews and Tedesco, 1992), provides important additional information for the identification of H-layers.

Bulk carbonate concentration profiles show characteristic variations in H-layers that can be correlated between cores (Fig. 6). Increases in carbonate concentration are also associated with variations in magnetic susceptibility and IRD content (Figs. 3 and 5) (Rashid, 2002). The magnetic susceptibility in $\mathrm{H} 1$ and $\mathrm{H} 2$ of the NW Labrador Sea (MD99-33; see also Rashid et al., 2003a for Hu97-16) is lower, consistent with the earlier findings of a similar relationship between the high bulk carbonate and low magnetic susceptibility for $\mathrm{H} 1$ and $\mathrm{H} 2$ for the same region (Andrews and Tedesco, 1992). In contrast, the susceptibility values are high in the southern Labrador site (Pa96-06) (Fig. 5), similar to the susceptibility values reported in identifying the H-layer in the open North 


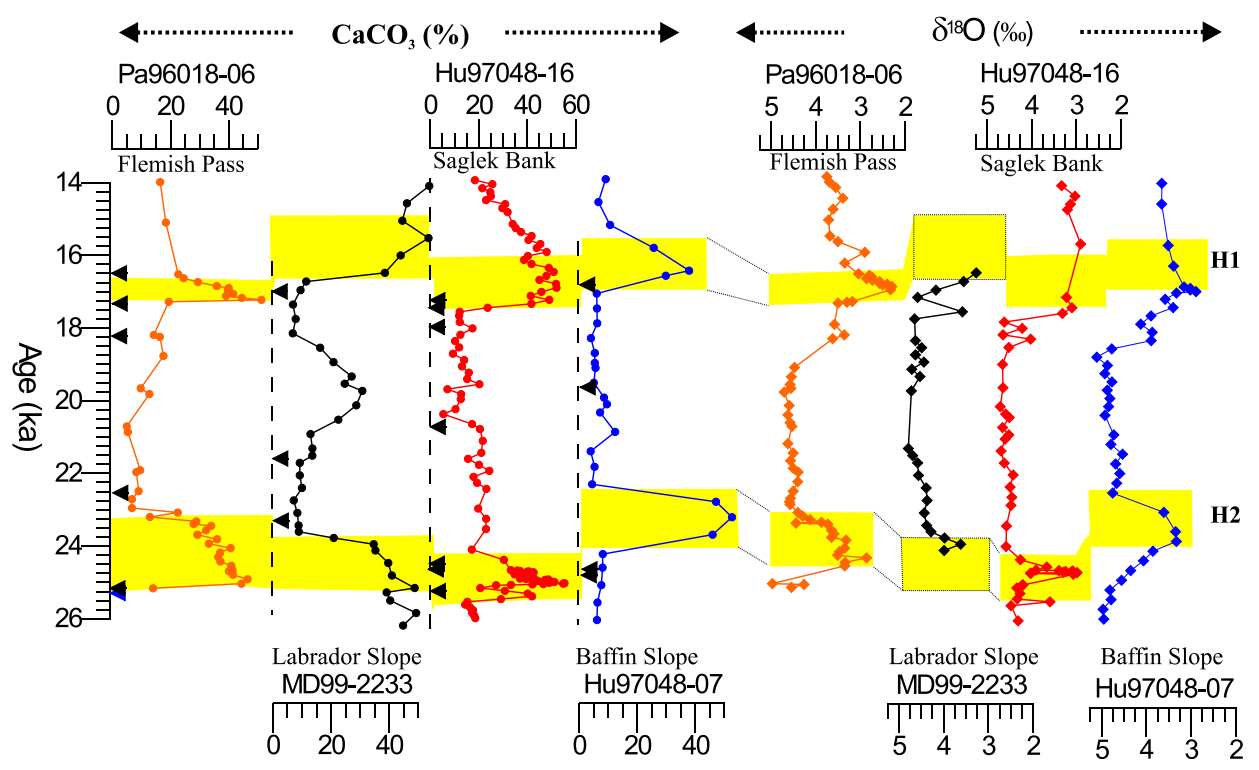

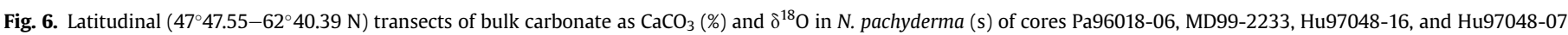

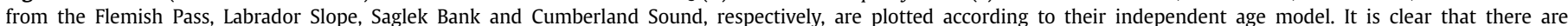

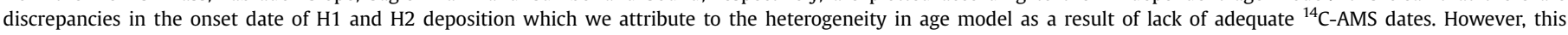
heterogeneity in age model cannot account for the large time offset in the onset date of $\mathrm{H} 1$ and $\mathrm{H} 2$ between the Cumberland Sound and Hudson Strait discharges.

Atlantic (Grousset et al., 1993). The IRD profile shows highfrequency internal variations in $\mathrm{H} 1$ and $\mathrm{H} 2$, with two maximum amplitudes at the base and the top of the H-layers which correspond to units A and C (Fig. 4). In unit B, which corresponds to the nepheloid-flow deposit, a reduction in the IRD content is observed (Fig. 2). This reduction in IRD correlates to the highest carbonate concentration, with value ranging from $55 \%$ to $40 \%$ and $60 \%$ to $50 \%$ in $\mathrm{H} 2$ and $\mathrm{H} 1$ (Fig. 6), respectively, from the NW Labrador Sea to Flemish Pass (Figs. 2-5). At the southern sites, the thickness of $\mathrm{H}-$ layers decreases and the two peaks observed in the IRD profiles for $\mathrm{H} 1$ and $\mathrm{H} 2$ appear narrower.

In comparison to Hudson Strait, deep Labrador Sea, Flemish Pass and Orphan Knoll records, the data from SE Baffin Slope core Hu9707 (Fig. 2) show a different pattern. The highest carbonate concentration reaches $55 \%$ for $\mathrm{H} 2$ and $40 \%$ for $\mathrm{H} 1$. The carbonate concentration of $\mathrm{H} 2$ is closer to the Hudson Strait core Hu97-16 (Fig. 4), but the carbonate concentration of $\mathrm{H} 1$ is similar to those of Flemish Pass (Fig. 5) and Orphan Knoll (Fig. S2). The IRD content in $\mathrm{H} 2$ and $\mathrm{H} 1$ is low compared to those in cores farther south. The rise in IRD in Hu97-07 occurred after the decrease in the carbonate with an offset of $\sim 700$ years for $\mathrm{H} 2$ and $\sim 1400$ years for $\mathrm{H} 1$ (Fig. 2 ). In both events, no basal unit A was found, suggesting the deposition of only nepheloid-flow layers.

\subsection{Isotopic $(\mathrm{Sr}-\mathrm{Nd})$ composition of the $<63 \mu \mathrm{m}$ fraction}

We have plotted all the published pertinent $\varepsilon_{\mathrm{Nd}}$ and ${ }^{87} \mathrm{Sr} /{ }^{86} \mathrm{Sr}$ data from the ice-proximal glacial-marine and basal till deposits to "ambient" open Labrador Sea and North Atlantic sediments (Barber, 2001; Grousset et al., 2001; Farmer et al., 2003; Verplanck et al., 2009) in Fig. 7.

Five distinct sources of Nd can be identified from Greenland to the NE Canadian margin (Figs. 1 and 7). The majority of our sourcetype samples are from an area termed the "greater Hudson Strait region", i.e., northern Hudson Bay, Hudson Strait, and the SE Baffin Island shelf (Table 3). Iceland/Faroe Island and East Greenland sediments clearly show a distinct isotopic signature such that the Icelandic sediments are identified with high $\varepsilon_{\mathrm{Nd}}$ and low ${ }^{87} \mathrm{Sr} /{ }^{86} \mathrm{Sr}$ with values ranging from 5.3 to 8.01 and 0.7046 to 0.7034 , respectively. East Greenland sediments show a different isotopic signature with the $\varepsilon_{\mathrm{Nd}}$ and ${ }^{87} \mathrm{Sr} /{ }^{86} \mathrm{Sr}$ values ranging from -25 to -40 and 0.7220 to 0.7302 , respectively. Sediment from the Norwegian Sea and Gulf of St. Lawrence have a distinct signature as well, with low $\varepsilon_{\mathrm{Nd}}(-14.22$ to -20.10$)$ and high ${ }^{87} \mathrm{Sr} /{ }^{86} \mathrm{Sr}$

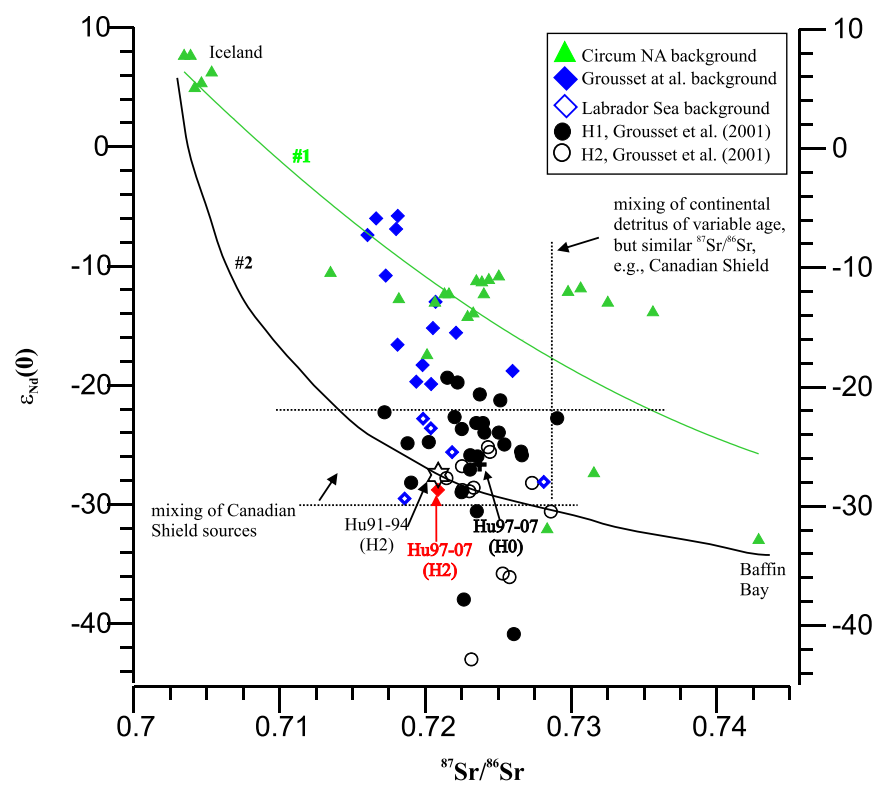

Fig. 7. $\varepsilon_{\mathrm{Nd}}$ versus ${ }^{87} \mathrm{Sr} /{ }^{86} \mathrm{Sr}$ of samples from $\mathrm{H} 0, \mathrm{H} 1$, and $\mathrm{H} 2$ as well as background sediments of the greater Labrador Sea margin and circum-North Atlantic. The curve (\#2) was used by Grousset et al. (1993) to demonstrate mixing between the sediment sources of Iceland and Baffin Bay. The vertical and horizontal lines indicate mixing of continental sources of various ages (but with similar ${ }^{87} \mathrm{Sr} /{ }^{86} \mathrm{Sr}$ ) and mixing of Archean sources with a range of $\mathrm{Rb} / \mathrm{Sr}$ (Hemming et al., 1998). The curvature of the IcelandBaffin Bay mixture is a function of the $\mathrm{Sr} / \mathrm{Nd}$ concentration ratio in basalt sources compared to continental crust. Note that the data do not conform to a simple mixing relationship between the Iceland source and those of the H-layers but rather require a much broader range of continental end members as earlier described by Hemming et al. (1998). Note also that the Labrador Sea $\varepsilon_{\mathrm{Nd}}$ and ${ }^{87} \mathrm{Sr} /{ }^{86} \mathrm{Sr}$ ratios of $\mathrm{HO}, \mathrm{H} 1$ and $\mathrm{H} 2$ are indistinguishable from those of the North Atlantic. Various symbols indicate samples within the IRD-belt and from north of it. 
Table 3

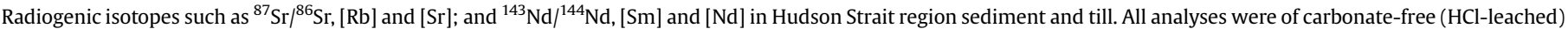

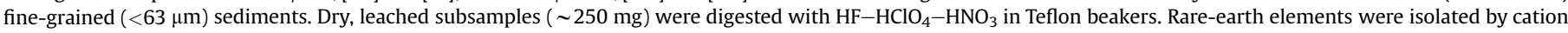
exchange (6 $\mathrm{HNO}_{3}$ elution), Sm and $\mathrm{Nd}$ separated on anionic resin (0.4 and $0.6 \mathrm{~N} \mathrm{HCl}$ elutions, respectively). (Barber, 2001)

\begin{tabular}{|c|c|c|c|c|c|c|c|c|c|}
\hline Sample depth (cm) & Source type ${ }^{a}$ Straigraphic unit & $\mathrm{Rb}^{\mathrm{b}}(\mathrm{ppm})$ & $\mathrm{Sr}(\mathrm{ppm})$ & ${ }^{87} \mathrm{Sr} /{ }^{86} \mathrm{Sr}^{\mathrm{c}}$ & $\mathrm{Sm}^{\mathrm{b}}(\mathrm{ppm})$ & $\mathrm{Nd}(\mathrm{ppm})$ & ${ }^{147} \mathrm{Sm} /{ }^{144} \mathrm{Nd}$ & ${ }^{143} \mathrm{Nd} /{ }^{144} \mathrm{Nd}^{\mathrm{d}}$ & $\varepsilon_{\mathrm{Nd}}(0)^{\mathrm{e}}$ \\
\hline \multicolumn{10}{|l|}{ NE Hudson Bay } \\
\hline Hu87028-04 & W. Hudson Bay, Coats Island & & & & & & & & \\
\hline $514-516$ & Red-grey, ice-contact diamict & 61.20 & 252.19 & $0.723292 \pm 13$ & 3.32 & 16.42 & 0.1223 & 0.511360 & -24.9 \\
\hline \multicolumn{10}{|l|}{ W Basin, Hudson Strait } \\
\hline Hu90023-101 & Ice from WNW of Hudson Strait & & & & & & & & \\
\hline $68-70$ & Post-glacial & 52.44 & 285.34 & $0.719989 \pm 18$ & 2.96 & 14.89 & 0.1202 & 0.511236 & -27.3 \\
\hline 200-202 & Red bed, gm & 84.55 & 221.71 & $0.724853 \pm 14$ & 3.54 & 18.57 & 0.1152 & 0.511254 & -27.0 \\
\hline $212-215$ & Red bed, gm & & 170.02 & $0.722038 \pm 23$ & 2.70 & 13.99 & 0.1168 & 0.511414 & -23.8 \\
\hline $398-400$ & Ice-proximal, gm & 53.52 & 189.36 & $0.721773 \pm 18$ & 3.17 & 16.88 & 0.1138 & 0.511194 & -28.2 \\
\hline $727-729$ & Ice-proximal, gm & 54.16 & 127.18 & $0.725887 \pm 10$ & 2.57 & 13.17 & 0.1181 & 0.511197 & -28.1 \\
\hline \multicolumn{10}{|c|}{ E Basin, Hudson Strait } \\
\hline Hu90023-045 & Ice-proximal, gm & & & & & & & & \\
\hline $554-558$ & Ice-proximal, gm & 44.17 & 155.51 & $0.722620 \pm 13$ & & 10.34 & & 0.511226 & -27.3 \\
\hline $654-656$ & Red bed, gm & 44.84 & 212.33 & $0.720353 \pm 18$ & & 10.19 & & 0.511237 & -27.5 \\
\hline $1050-1052$ & Ice-distal, gm & 50.52 & 185.39 & $0.721470 \pm 9$ & 2.4 & 14.26 & 0.1017 & 0.511310 & -25.9 \\
\hline Hu93034-004P & Labrador Dome & & & & & & & & \\
\hline 201-203 & Proximal/distal, gm & 49.19 & 247.56 & $0.720535 \pm 14$ & & & & 0.511248 & -27.1 \\
\hline \multicolumn{10}{|l|}{ Cumberland Sound } \\
\hline $778-782$ & Ice-contact diamict & & 98.74 & $0.745654 \pm 9$ & 1.99 & 11.26 & 0.1069 & 0.511141 & -29.2 \\
\hline \multicolumn{2}{|l|}{ NW Hudson Bay } & \multicolumn{8}{|c|}{ Keewatin Dome } \\
\hline 76 KB0037 & Dubawnt Till & & 127.97 & $0.742873 \pm 14$ & 1.52 & 9.14 & 0.1004 & 0.510952 & -32.9 \\
\hline \multicolumn{2}{|l|}{ NE Quebec } & \multicolumn{8}{|c|}{ Labrador Dome } \\
\hline 86TBA 2209-3 & Unspecified till & & 229.18 & $0.723667 \pm 16$ & 3.5 & 22.24 & 0.0952 & 0.510845 & -35.0 \\
\hline \multicolumn{2}{|l|}{ Cumberland Sound } & \multicolumn{8}{|c|}{ Local ice-caps, Cape Mercy } \\
\hline GRL-10680 & Unspecified till & 68.65 & 382.56 & $0.722154 \pm 18$ & 2.32 & 13.99 & 0.1004 & 0.511077 & -30.5 \\
\hline \multicolumn{2}{|l|}{ Ungava Bay, Akp. Is. } & \multicolumn{8}{|c|}{ Local Paleoz. limestone } \\
\hline GRL-8395 & Residual clastics & 130.42 & 68.08 & $0.756528 \pm 50$ & 1.27 & 10.84 & 0.0709 & 0.511625 & -19.8 \\
\hline
\end{tabular}

a Lithostratigraphic unit (slope cores) or sources of ice and sediment (shelf cores) (after Barber, 2001).

b Element concentrations by isotope dilution. Uncertainties are $-0.5 \%$ (Farmer et al., 1991). Total procedural blanks for Sm and Nd are 50 and 500 pg, respectively.

${ }^{c}{ }^{87} \mathrm{Sr} /{ }^{86} \mathrm{Sr}$ ratios were obtained of Finnegan-MAT 261 solid-source mass spectrometer at the University of Colorado using four-collector static mode measurements cor-

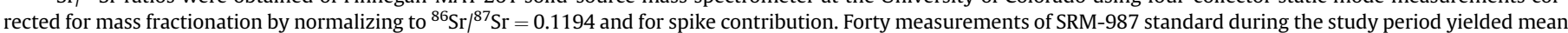
${ }^{87} \mathrm{Sr} /{ }^{86} \mathrm{Sr}=0.71031 \pm 1(2 \sigma$ external precision). Errors are $2 \sigma$ (in-run mean) and refer to the last significant figures.

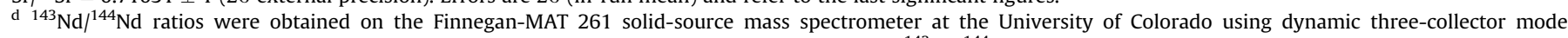

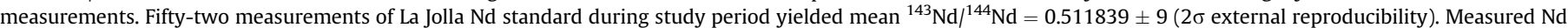
isotopic ratios normalized to ${ }^{146} \mathrm{Nd} /{ }^{144} \mathrm{Nd}=0.7219$. Errors are $2 \sigma$ (in-run mean) and refer to the last significant figures.

e Measured $\varepsilon$ Nd values calculated assuming a present-day ${ }^{143} \mathrm{Nd} /{ }^{144} \mathrm{Nd}(\mathrm{CHUR})=0.512638$.

(0.7316-0.7293). The fifth region shows $\varepsilon_{\mathrm{Nd}}$ and ${ }^{87} \mathrm{Sr} /{ }^{86} \mathrm{Sr}$ values ranging from -36 to -45 and 0.72 to 0.733 , respectively. These values are attributed to West Greenland and/or Newfoundland derived sources. The $\varepsilon_{\mathrm{Nd}}$ and ${ }^{87} \mathrm{Sr} /{ }^{86} \mathrm{Sr}$ ratios in the SE Baffin slope core Hu97-07 vary from -25 to -29 and $\sim 0.721$ for $\mathrm{HO}$ and $\mathrm{H} 2$, respectively. These $\varepsilon_{\mathrm{Nd}}$ ratios are close to those ratios measured in the H-layers of the North Atlantic IRD-belt $\left(\varepsilon_{\mathrm{Nd}}=-25\right.$ to -35$)$ (Hemming et al., 1998; Grousset et al., 2001; Farmer et al., 2003; Verplanck et al., 2009).

\section{Discussion}

\subsection{Past surface water reservoir ages in the Labrador Sea and North Atlantic}

Accurate surface water reservoir age estimate is necessary to determine the leads and lags among climate events in marine records. In recent years significant progress has been made in assessing the surface water reservoir age in both the Labrador Sea and the North Atlantic Ocean. This progress has reduced the uncertainty in regional reservoir anomaly $(\Delta R)$ estimate and hence allowed correlation of many short-lived freshwater discharge events especially in the eastern Canadian continental margin stretching $\sim 2000 \mathrm{~km}$ range (Lewis et al., 2012). We use a $\Delta \mathrm{R}$ of 50 years in addition to 400 years already incorporated in the calibration program (Reimer et al., 2009) for converting the ${ }^{14} \mathrm{C}$-AMS dates to calendar years to construct age model of the Labrador Sea records. This $\Delta R$ of 50 years is most likely a minimal estimate for the Holocene conditions in the Labrador Sea, as it could vary up to a few hundred years (McNeely et al., 2006; Hillaire-Marcel et al., 2007; Rashid et al., 2011; Lewis et al., 2012). For example, pre-industrial $\Delta R$ for infaunal molluscs in Hudson Bay (275 \pm 40 years), Hudson Strait (125 \pm 40 years), and Labrador and Newfoundland shelves and upper slope waters (144 \pm 38 years) show variable ages (McNeely et al., 2006). By estimating the duration of sea-ice cover using dinoflagellate assemblage transfer function, Lewis et al. (2012) inferred that even if the Labrador margin were to be covered by sea-ice for 12 months/year, this $\Delta R$ would not exceed more than 300 years. At any rate, since we applied a constant $\Delta R$ value to all our Labrador Sea records, we suggest that any change in the $\Delta R$ of less than 300 years must not change the identification of $\mathrm{HO}, \mathrm{H} 1$ and $\mathrm{H} 2$ and hence the basic tenet of our conclusions will also not change.

From the Norwegian margin, Bondevik et al. (2006) estimated a $\Delta R$ of 371 years for the Younger Dryas (YD) period, which was independently verified by Stanford et al. (2006) from the Eirik Drift. In addition, the $\Delta R$ could be as large as $\sim 2000$ years in the NE North Atlantic for the H1 (Waelbroeck et al., 2001; Peck et al., 2008). Using records from SU90-09, CHN82-20, and SU81-18, Rashid et al. (2010) reported zonal and meridional gradients in $\Delta R$ for the $\mathrm{YD}$ and $\mathrm{H} 1$ periods. These findings for $\mathrm{YD}$ and $\mathrm{H} 1$ periods seem to be corroborated by the updated $\Delta R$ estimate in Stanford 
et al. (2011). In any event, our main objectives in this contribution are to determine the leads and lags in discharge among various icestreams and ice-shelve of the LIS. In addition, we provide a conceptual framework between the eastern and western margin of the North Atlantic. Therefore, the uncertainty in $\Delta R$ estimate should not undermine the framework as it is not suggested which side of the Atlantic margin destabilized first; we simply outline the instability of ice-margins depositional process (see section 4.3.3).

\subsection{Timing of Cumberland Sound ice-shelf and Hudson Strait ice- stream response}

Understanding the synchroneity of instability among the iceshelf and ice-streams of the eastern sector of the LIS such as Cumberland Sound, Hudson Strait and Trinity Trough during the last deglaciation has been complicated by many problems. One of the most important has been the lack of high accumulation rate sediment cores with dense age control. Fortunately, two records from cores Hu97-07 (Fig. 2) and Hu97-16 (Fig. 4) have sufficiently high sedimentation rates and dense enough age control to allow assessment of the dynamics of the Hudson Strait ice-stream and Cumberland Sound ice-shelf. We plot the IRD content, $\mathrm{CaCO}_{3}(\%)$ and $\delta^{18} \mathrm{O}$ data from these cores according to their independent age models in Fig. 8 to illustrate such ice-streams dynamics.

Baffin Island has been implicated as one of the main sources of IRD found in the H-layers of the IRD-belt (Andrews and Tedesco, 1992; Grousset et al., 1993). Cumberland Sound hosted one of the ice-shelves for the NE part of the LIS, and it is known to have been occupied by grounded glacial ice-sheet at least until the YD

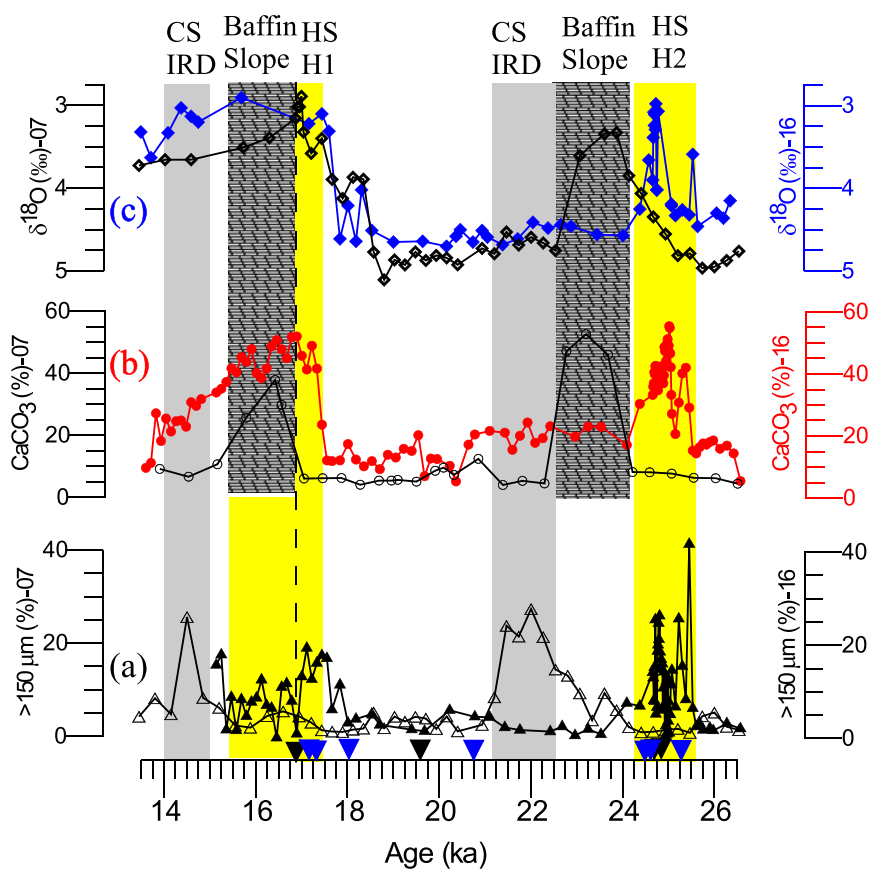

Fig. 8. Plots of (a) coarse fraction (\% $>150 \mu \mathrm{m})$, (b) bulk carbonate as $\mathrm{CaCO}_{3}(\%)$, and (c) $\delta^{18} \mathrm{O}$ in N. pachyderma (s) from cores Hu97-07 (left-hand axes) and Hu97-16 (righthand axes) which were collected from Baffin Slope and Hudson Strait, respectively. ${ }^{14} \mathrm{C}$ AMS dates of cores Hu97-07 and Hu97-16 are shown by the black and blue triangles, respectively. Vertical yellow and hatchet bars represent high carbonate intervals whereas the grey bars exhibit Cumberland Sound (CS)-IRD intervals. Note the dramatic offset in all three parameters between the cores from 21.50 to $25.60 \mathrm{ka}$ encompassing the $\mathrm{H} 2$. Note also the large time offset between the carbonate (b) and coarse fraction (a) profiles at the onset of H1-layer, however this time offset is near absent in the $\delta^{18} \mathrm{O}$ profiles (c). (For interpretation of the references to color in this figure legend, the reader is referred to the web version of this article.)
(Jennings, 1993). Erosion of Cretaceous black shale has resulted in the accumulation of dark-color sediments (Jennings, 1993). Therefore, the presence of this sediment in core Hu97-07 indicates transport by the Cumberland Sound ice. It has been suggested that the sequence of stacking of the detrital carbonate and black shale units indicates changes in the dynamics between the Hudson Strait ice-stream and Cumberland ice-shelf (Andrews and MacLean, 2003). However, this concept was put forward without ascertaining the timing and synchroneity of the sediment sequences. This is an important point to assess, as the Hudson Strait ice-stream has been described as more unstable than the other North Atlantic icestreams (Bond and Lotti, 1995; Dowdeswell et al., 1999; Grousset et al., 2000), even though the Cumberland Sound ice-shelf should be prone to frequent instabilities because of its small size.

In the SE Baffin Slope core Hu97-07, H2 is identified by an abrupt increase in the bulk carbonate and nepheloid-flow deposit structure as illustrated in the X-radiographs (Figs. 2 and S1). However, the depletion in $\delta^{18} \mathrm{O}$ leads the increase in bulk carbonate by $\sim 1 \mathrm{kyr}$ and increase in coarse fraction ( $\%>150 \mu \mathrm{m})$ by $\sim 400$ years. Furthermore, the coarse fraction begins to rise prior to the decrease of bulk carbonate towards the top of $\mathrm{H} 2$. These coarse fractions were mostly derived from the stratified diamict in which the carbonate concentration is close to that of Labrador Sea ambient sediment (Rashid and Piper, 2007). The near lack of an increase in carbonate within the coarse fraction between 21.2 and 22.6 ka suggests that the Hudson Strait-derived sediment supply reaching the Hu97-07 locality waned or halted during this time (Fig. 8). This interval appears to be comprised instead of dark sediment eroded from Cumberland Sound (Maclean et al., 1986; Jennings et al., 1996). In contrast, the offset among $\delta^{18} \mathrm{O}$, carbonate, and coarse fraction in $\mathrm{H} 2$ in the Hudson Strait core Hu97-16 is nearly absent (Fig. 4). It is noteworthy that the increase in coarse fraction (postdating both $\mathrm{H} 2$ and $\mathrm{H} 1$ ) in the SE Baffin Slope core Hu97-07 did not significantly perturb the $\delta^{18} \mathrm{O}$, suggesting that most likely ice calving from Cumberland Sound iceshelf was not significant. Indeed, the lack of visible dark layers above $\mathrm{H} 2$ and $\mathrm{H} 1$ south of Cumberland Sound indicates that the plume related to the meltwater was restricted to the vicinity of the ice front, and IRD input was too small to form a distinct unit.

In contrast to $\mathrm{H} 2$, the onset of depletion in $\delta^{18} \mathrm{O}$ precedes the rise of carbonate by $\sim 1.8 \mathrm{kyr}$ for $\mathrm{H} 1$ in core Hu97-07 (Fig. 2). The coarse fraction content begins to increase after the diminishment of carbonate to the Labrador Sea background level after H1 (Fig. 8). The resumption of depletion in $\delta^{18} \mathrm{O}$ at $18.6 \mathrm{ka}$ is most likely due to the response to increase in insolation of the Northern Hemisphere during the last deglaciation (Rashid et al., 2011; Stanford et al., 2011). The onset of depletion in $\delta^{18} \mathrm{O}$ in core Hu97-16 was found at $18.5 \mathrm{ka}$, preceding the rise in carbonate by $\sim 400$ years (Rashid et al., 2011). The coarse fraction increases concurrently with those of the carbonates. A question could be raised about the impact of bioturbation in homogenizing sediments and thus cast doubt about the leads and lags found in these records. Sedimentation rates in both cores vary from 12 to 31 and 15 to $34 \mathrm{~cm} / \mathrm{kyr}$, especially during $\mathrm{H} 1$ and $\mathrm{H} 2$, respectively, which is sufficiently high not to be blurred by the bioturbation (Trauth et al., 1997; Anderson, 2001). Additionally, the X-radiographs allow us to assess the effect of bioturbation, which we find to be minimal; however, a minor impact of bioturbation cannot entirely be ruled out.

In comparison to Hu97-07 and Hu97-16, the records from the Orphan Knoll core Hu91-94 (Fig. S2) are rather instructive in terms of phasing between the carbonate and $\delta^{18} \mathrm{O}$. It should be mentioned a priori that the temporal resolution in this record varies from 10 to 100 years and the sedimentation rate ranges from 14 to $26 \mathrm{~cm} / \mathrm{kyr}$ for the interval encompassing $\mathrm{H} 1$ and $\mathrm{H} 2$ (Hillaire-Marcel et al., 1994). In contrast to the findings in cores Hu97-07 and Hu97-16, the rise in carbonate leads the onset in depletion of $\delta^{18} \mathrm{O}$ by 
500-600 years during $\mathrm{H} 0, \mathrm{H} 1$ and $\mathrm{H} 2$. Thus, our data suggest that there should be a time lag in onset between the Hudson Strait and southern Labrador Sea records as far as the deposition of H0, $\mathrm{H} 1$ and $\mathrm{H} 2$ is concerned.

In summary, it is clear from records of cores Hu97-07 and Hu9716 that the Hudson Strait sediment was released first and then the Cumberland Sound sediments were deposited during $\mathrm{H} 2$ and $\mathrm{H} 1$. Our data thus suggest that the Hudson Strait ice-stream became unstable, initially ushering an iceberg surge and releasing meltwater-laden fine-grained sediment. The deposition of the Cumberland Sound source sediments possibly arose as a result of a rise in sea-level (Grousset et al., 2001) and domino effects in instability on the ice-shelves and ice-streams (Hulbe et al., 2004; Bigg et al., 2011).

\subsection{The fine internal structure of the Labrador Sea $\mathrm{H} 1$ and $\mathrm{H} 2$}

\subsubsection{Significance of the H1-H2 IRD peaks}

The abundance of $N$. pachyderma (s) in conjunction with changes in the $\delta^{18} \mathrm{O}_{\mathrm{Nps}}$ is often used to track changes in the North Atlantic and Labrador Sea sea-surface conditions (Bond et al., 1993; Wu and Hillaire-Marcel, 1994; Chapman et al., 2000). In an ice marginal setting, such as near the mouth of the Hudson Strait, these proxies may relate to carbonate content and IRD which were used as proxies for meltwater and iceberg discharge, respectively, in the NW Labrador Sea (Thomas et al., 2003; Rashid et al., 2003a).

Along the NW Labrador margin, the onset of an H-event is accompanied by a sharp increase in the number of large dropstones contained within hemipelagic sediment (Rashid et al., 2003a). Dropstones in the initial IRD peak found at the base of $\mathrm{H} 1$ and $\mathrm{H} 2$ in core Hu97-16 were characterized by clasts of (pinkish/whitish) limestone that we designated as unit A (Fig. 4). At the onset of the first IRD peak, neither an appreciable increase in bulk carbonate nor depletion in $\delta^{18} \mathrm{O}_{\mathrm{Nps}}$ occurred, suggesting a lack of significant meltwater discharge. The middle unit (unit B), interpreted as a nepheloid-flow deposit, shows a sharp increase in carbonate content and the abundance of $N$. pachyderma (s) (Thomas et al., 2003). In the upper unit (unit C), nepheloid-flow deposit disappeared abruptly and the concentration of dropstones increase, as shown by a second IRD peak. Thus, $\mathrm{H} 1$ and $\mathrm{H} 2$ in Hu97-16 show two IRD peaks at the base and at the top, while in unit B the IRD peak is barely visible (Fig. 4) (Rashid et al., 2003a).

The Labrador Rise and deep basin cores are characterized by unique features during the deposition of $\mathrm{H} 1$ and $\mathrm{H} 2$ (Fig. S3). Increased $\delta^{18} \mathrm{O}$ values and the abundances of $N$. pachyderma $(\mathrm{s})$ suggest that $\mathrm{H} 1$ and $\mathrm{H} 2$ began when the sea-surface was cold, as described above (Khodabakhsh, 1997; Rashid and Piper, 2007). There is a sharp increase in bulk carbonate at the base of $\mathrm{H} 2$, which coincides with the peak in the IRD. A degree of internal variability in IRD within $\mathrm{H} 2$ in core Hu90-26 (Fig. S3) was observed which was possibly due to the dispersion of randomly oriented dropstones in the graded muds and thin laminae of IRD. Decreased $\delta^{18} \mathrm{O}$ values appeared to be either coeval or somewhat lagging behind the IRD peak in both $\mathrm{H} 1$ and $\mathrm{H} 2$ (Fig. S3).

Around the Flemish Pass, a similar record is observed, with a sharp increase in carbonate and IRD in core Pa96-06 (Fig. 5). The basal peak in IRD is composed white sandy limestones. The carbonate concentration remains high throughout $\mathrm{H} 1$ and $\mathrm{H} 2$. However, IRD content is reduced nearly to the background level towards the top of the interval for both H1 and H2 (Fig. 5). Grey limestone is particularly common in $\mathrm{H} 1$ and $\mathrm{H} 2$, which may be derived from the Lower Paleozoic rocks of the northern Gulf of St. Lawrence and adjacent SE Québec and northern Newfoundland (Piper and de Wolfe, 2003). However, at the top of the Flemish Pass, $\mathrm{H} 2$ shows high abundance of granitic IRD (Piper and de Wolfe,
2003) which would reflect calving of icebergs from crystalline bedrock regions of Greenland and Baffin Island after the initial discharge of icebergs from the Hudson Strait was completed.

High-resolution data from the Orphan Knoll core Hu91-94 (Fig. S2) have shown that both $\mathrm{H} 1$ and $\mathrm{H} 2$ exhibit two IRD peaks (Hillaire-Marcel et al., 1994; Stoner et al., 1998; Clarke et al., 1999). The first IRD peak at the base has a proportion of pinkish, sand-sized carbonate grains typically exceeding $50 \%$, overlain by fine-grained carbonate, which shows a sharp increase followed by gradual decrease (Clarke et al., 1999). A thick layer with increased finegrained carbonate above the basal peak in H-layer, equivalent to the nepheloid-flow deposit found in the NW Labrador Sea and deep Labrador basin cores (Hesse and Khodabakhsh, 1998; Rashid et al., 2003a; Rashid and Piper, 2007), is most likely the result of deposition from a turbid plume carried by the prevailing Labrador Current to Flemish Pass which rained down finer particles from the turbid cloud. This interpretation is consistent with the data from core Pa9606 where the basal IRD peak is overlain by fine-grained carbonate, which does not appear to show any appreciable increase in grain size. Deposition from a turbid plume would require a significant amount of time, consistent with the duration of H-layers in the Labrador Sea (Veiga-Pires and Hillaire-Marcel, 1999). The second IRD peak reported for $\mathrm{H} 1$ and $\mathrm{H} 2$ in core Hu91-94 (Fig. S2) does not show any appreciable increase in the coarse fraction compared to the background level coarse fraction of the southern Labrador Sea (Fig. 3 of Clarke et al., 1999, p.246). In the upslope Flemish Pass core Pa96-06 (Fig. 5), the IRD data also do not show any appreciable increase in IRD content of the background sediment.

\subsubsection{Synoptic mixing of sediments in the North Atlantic during H1 and $\mathrm{H} 2$}

The availability of high temporal resolution data on cores from the mid-Atlantic inside the IRD-belt and west European ice-sheet (WEIS) region show that the $\mathrm{H} 1$ and $\mathrm{H} 2$ possess a three-layered structure (Bond and Lotti, 1995; Scourse et al., 2000; Grousset et al., 2001; Jullien et al., 2006; Lekens et al., 2009; Toucanne et al., 2009). As a result, numerous hypotheses were put forward to explain the mechanisms of formation of those records. For example, an IRD peak from the LIS is found sandwiched between two IRD peaks of European origin from a H-layer in the Bay of Biscay (Grousset et al., 2000; Zaragosi et al., 2001). In contrast to the Bay of Biscay records, $\mathrm{H} 1$ and $\mathrm{H} 2$ layers along the Portuguese margin show two depositional phases expressed by a weak basal peak that comprised detrital carbonate of LIS origin, and a top peak that consists of hematite-coated grains (Bond et al., 1993; Auffret et al., 1996; Lebreiro et al., 1996; Bard et al., 2000).

The apparent discordance in the sequence of IRD in $\mathrm{H} 1$ and $\mathrm{H} 2$ peaks from the same European margin could perhaps be reconciled by closely investigating ice-margin depositional processes. Closer to the ice-proximal setting of the LIS, three distinct lithologic units (A, $\mathrm{B}$, and C) (Fig. 4), were identified that operated sequentially during the deposition of $\mathrm{H} 1$ and $\mathrm{H} 2$ (Rashid et al., 2003a). These units are present in cores from the outer shelf/upper slope sites in the NW Labrador Sea near the mouth of the Hudson Strait. However, the deep Labrador Basin sites show only two lithologic units (B and C) that have one coeval carbonate and IRD peak (Hesse and Khodabakhsh, 1998). On the Flemish Pass, a lag between IRD peaks and $\delta^{18} \mathrm{O}_{\mathrm{Nps}}$ peaks at the start of $\mathrm{H} 2$ and $\mathrm{H} 1$ suggest a delay with Hudson Strait trough mouth. Increased $\delta^{18} \mathrm{O}_{\mathrm{Nps}}$ values suggest that the Labrador sea-surface was cold at the time of the first IRD peak. This lag is most likely similar to the findings in the mid-Atlantic (Auffret et al., 1996; Knutz et al., 2007). The decrease in $\delta^{18} \mathrm{O}_{\mathrm{Nps}}$ values is correlated with the climax of meltwater input, which also corresponds to the occurrence of facies B in the north (Fig. 4). Thus, we propose that the lag observed between the peaks is the result of 
an intensification of meltwater release (facies B) occurring after the first step of ice calving (facies A). The meltwater would be transported southward and enter into the North Atlantic Ocean, inducing a decrease in surface salinity and cooling sea-surface temperature (Chapman et al., 2000). This Heinrich-related event would explain the decrease in IRD and the drastic environmental change. A similar process may have occurred along the NW and western European margin (Henrich et al., 1989; Baas et al., 1997; Dowdeswell and Elverhøi, 2002; Lekens et al., 2005; Sejrup et al., 2005).

Based on the data presented from the Labrador Sea to the Western European margin, we hypothesize that the North Atlantic $\mathrm{H}$-layers most likely represent the equivalent to unit $\mathrm{C}$ of the NW Labrador Sea as shown by a schematic in Fig. 9. We further hypothesize that only the unit $\mathrm{C}$ represents the LIS signal offshore Portugal and along the eastern European margin (Fig. 9). The discordance between the findings from the Bay of Biscay and Portugal Margin is most likely similar to the differences between North Labrador sites and the Flemish Pass records. Any significant change in the ice-sheet dynamics would be recorded close to the ice-sheet margin, while the distal locations would only record extreme events (Fig. 9). Our proposed hypothesis illustrates the processes which may have operated during the deposition of an $\mathrm{H}-$ layer in both east and west sides of the North Atlantic.

\subsubsection{Implications for Heinrich Event models}

At a fine scale, the structure of $\mathrm{H} 1$ and $\mathrm{H} 2$ at the mouth of Hudson Strait shows multiple stages of deposition (stages A, B and C), i.e. ice calving (A) followed by meltwater input and ice calving (B), and finally by ice calving (C) (Fig. 10) (see also Rashid et al., 2003a). In contrast to the mouth of the Hudson Strait, cores from mid-Atlantic and Western Europe show a single process represented by IRD beds from different sources. Our data show that the increase in meltwater (facies B) occurred after the deposition of IRD (facies A). Facies B (Fig. 4), which comprises a rapid succession of IRD-rich beds interstratified with nepheloid-flow deposits and hemipelagic sediments corresponds to the time of maximum release of meltwater. This rapid lithologic succession within facies B does not occur randomly but clearly represents a seasonal signature (Hesse and Khodabakhsh, 1998; Hesse et al., 2004). This intermediate process is not captured in the open Atlantic sediment record due to the dissipation of nepheloid-flow and sediment plume with distance (Figs. 4 and 10). As a result, feeding numerical models with data only from the North Atlantic introduces an inherent bias in modeling H-events, and hence the appearance of variability in different ice sheets dynamics. In that respect, three depositional phases found in $\mathrm{H} 1$ and $\mathrm{H} 2$ in the northwest Labrador Sea sediment records contradict the numerical model results.

For example, in their seminal paper Alley and MacAyeal (1994) were able to reproduce the IRD peaks using the assumption that Heinrich layers would be the product of a single depositional (purge) process. As the model does not allow external forcing for generating H-events, no meltwater surge is possible without the ice-sheet reaching a critical size that would lead to melting of the ice sheet bed inland and surging along the ice-margin. In this model, production of IRD is directly related to freezing or melting of the base of the ice-sheet, suggesting that the IRD flux during an $\mathrm{H}-$ event would be glacial bed-dependent. But the model does not predict the facies $\mathrm{B}$, as this stage in the model is considered a time when the IRD flux goes to zero (Alley and MacAyeal, 1994).

More recent modeling results have suggested that subsurface warming could trigger H-events (Hulbe et al., 2004; Alvarez-Solas et al., 2010; Marcott et al., 2011). An abrupt heat supply due to major oceanic changes would induce a rapid dislocation of the iceshelves in the Hudson Strait and Labrador region, inducing a significant ice-stream break-up. In that scenario, different models
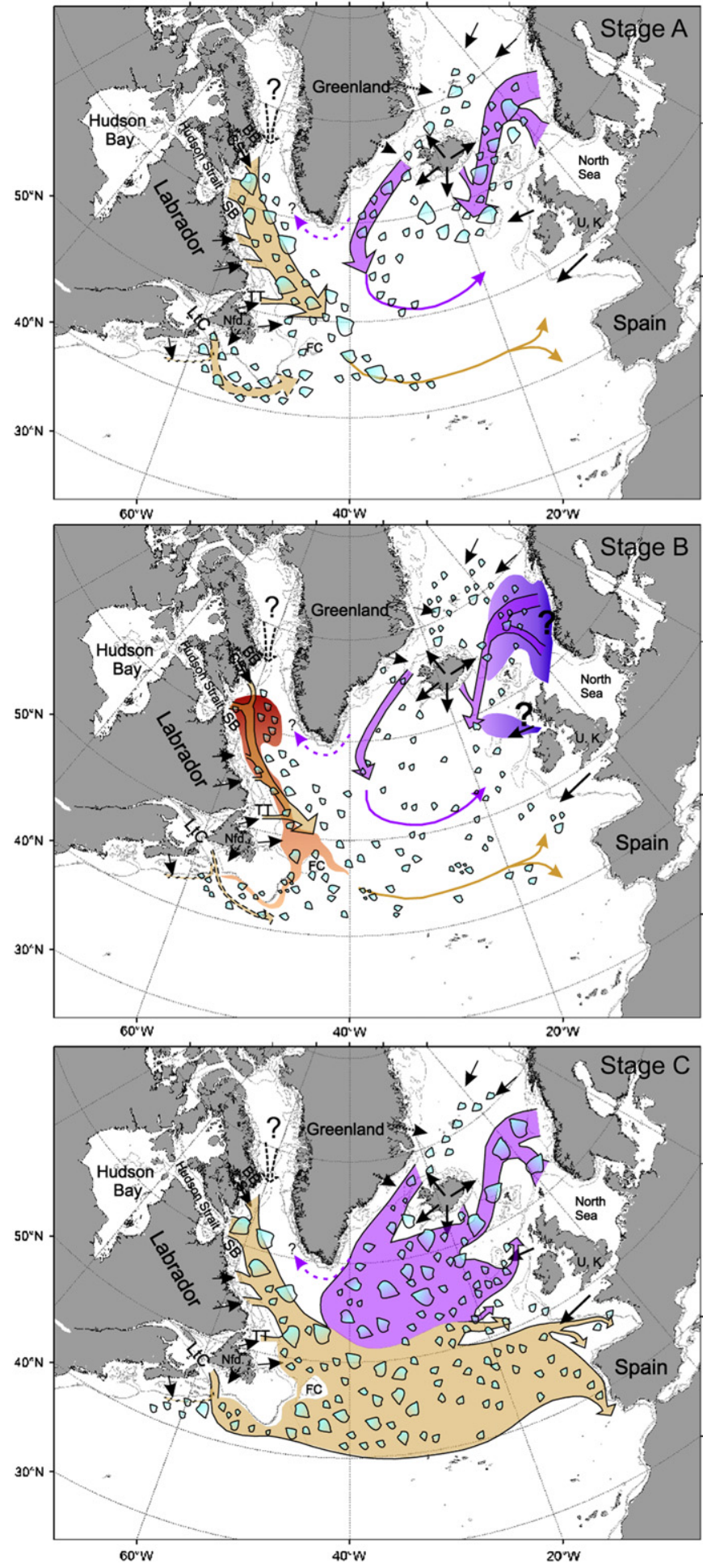

Fig. 9. Series of maps depicting the deposition of H-layers 1 and 2 in three stages in the Labrador Sea, North Atlantic and western European continental margin (see text for details). Note: BB = Baffin Bay; $C S=$ Cumberland Sound; SB = Saglek Bank; $\mathrm{TT}=$ Trinity Trough; Nfd. $=$ Newfoundland; FC = Flemish Cap; and LtC $=$ Laurentian Channel.

do not take into account (1) the fact that ice was grounded on the Labrador shelf until the Younger Dryas (Josenhans et al., 1986; Hall et al., 1999), and (2) these models do not differentiate seasonal meltwater input from ice calving stages, and are thus unable to predict facies B (Fig. 10). 

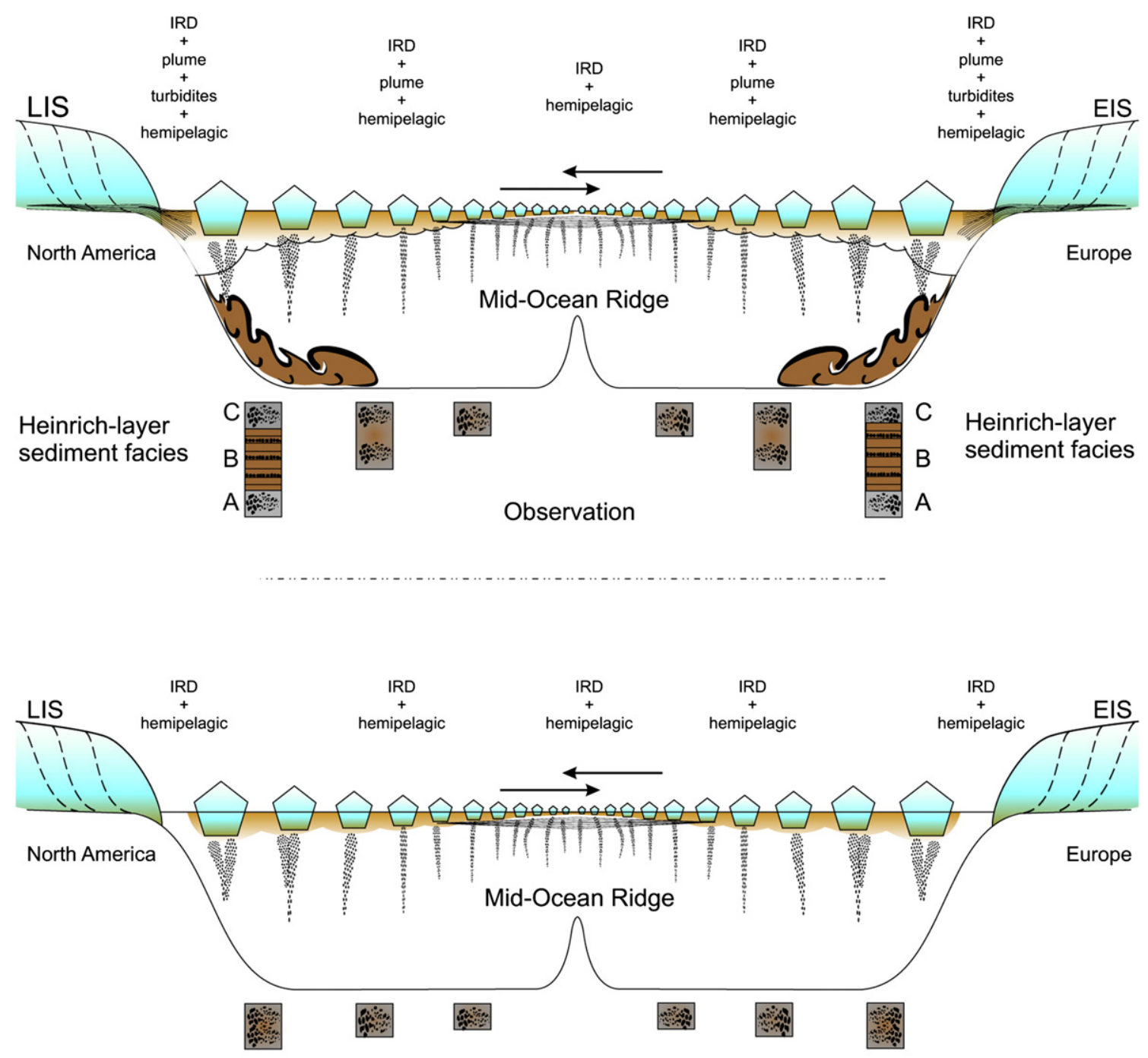

Models

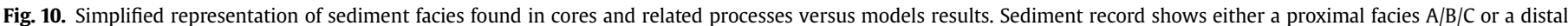

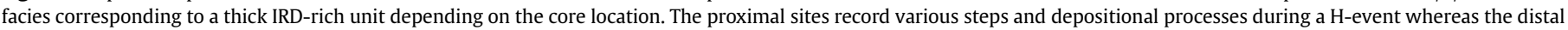

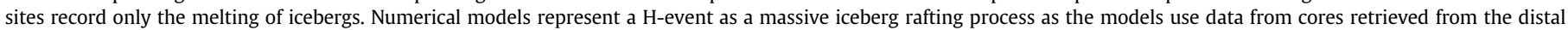
sites.

Numerous mechanisms have been proposed as a trigger for $\mathrm{H}-$ events in the past few years (Hulbe et al., 2004; Alley et al., 2006; Alvarez-Solas et al., 2010; Marcott et al., 2011) challenging the initial orbital forcing mechanism (Heinrich, 1988; Bond et al., 1992, 2001; Friedrich et al., 2009). Assessing the dynamic of circumNorth Atlantic ice-sheets collapse is a challenging task as the recording time and signature of an event strongly depends on the geographic location of the cores. Most of the proposed mechanisms for H-events are based on data obtained from cores retrieved from mid-Atlantic, i.e. far off Hudson Strait. Thus the sediment sampled from the mid-Atlantic represents only the final phase of the process (Fig. 10). As a consequence of the use of a single facies, i.e. an IRD rich unit, numerical ice-sheet modeling is failing to capture icemargin processes related to the deposition of facies B (Fig. 10).

\section{4. $\mathrm{HO}, \mathrm{H} 1$ and $\mathrm{H} 2$ radiogenic signature in North Atlantic}

An effort to fingerprint the sources of H-layers in the North Atlantic using radiogenic isotopes such as $\varepsilon_{\mathrm{Nd}}$ and ${ }^{87} \mathrm{Sr} /{ }^{86} \mathrm{Sr}$ in sediments has lead to ambiguous conclusions (Barber, 2001; Grousset et al., 2001; Farmer et al., 2003; Jullien et al., 2006; Peck et al., 2007). It was initially suggested that the sources of H-layers (except H3) were derived from Baffin Island, Baffin Bay, and western Greenland, not the Hudson Bay and Hudson Strait (Grousset et al., 1993). This conclusion was drastically revised in subsequent studies as a result of the availability of $\varepsilon_{\mathrm{Nd}}$ and ${ }^{87} \mathrm{Sr} /{ }^{86} \mathrm{Sr}$ data (Barber, 2001; Grousset et al., 2001; Farmer et al., 2003). These data demonstrate a dominant input from the LIS, especially from Hudson Bay via Hudson Strait (Barber, 2001; Farmer et al., 2003). Volcanic debris, hematite-stained grains and hornblendes are also present in the western part of the IRD-belt (Barber, 2001; Grousset et al., 2001; Farmer et al., 2003; Jullien et al., 2006). Because of their low $\varepsilon_{\mathrm{Nd}}$ and high ${ }^{87} \mathrm{Sr} /{ }^{86} \mathrm{Sr}$ ratios, this debris were interpreted to be derived from WEIS, East Greenland and Iceland (Grousset et al., 2001; Jullien et al., 2006). Nevertheless, several authors argued that the debris might have been provided by the LIS via Gulf of St. Lawrence (GSL), as the sediments flooring the St. Lawrence Channel have identical 
isotopic $\varepsilon_{\mathrm{Nd}}$ and ${ }^{87} \mathrm{Sr} /{ }^{86} \mathrm{Sr}$ ratios (Barber, 2001; Farmer et al., 2003; Peck et al., 2007; Stevenson et al., 2008).

One of the problems with such heterogeneous conclusions is the lack of radiogenic isotopic data from the Labrador Sea H-layers as well as ice-proximal surficial sediments of the greater Hudson Strait region (Farmer et al., 2003). Compilation of pertinent published $\mathrm{Nd}$ and $\mathrm{Sr}$ data (Fig. 7) indicates that there are significant differences between sediments along the East Greenland margin compared with the NE Canadian margin (Barber, 2001; Farmer et al., 2003; Verplanck et al., 2009). The $\varepsilon_{\mathrm{Nd}}$ and ${ }^{87} \mathrm{Sr} /{ }^{86} \mathrm{Sr}$ data show that the mantle-derived Icelandic source has a distinct isotopic signature compared to those of the Canadian Shield, Baffin Island and east Greenland source (Fig. 7) (Faure et al., 1963; Dasch, 1969). The mixing curve (\#2) between the Baffin Bay and Iceland source of Grousset et al. (1993) and the vertical line indicating mixing of continental source of various ages (but with the similar ${ }^{87} \mathrm{Sr} /{ }^{86} \mathrm{Sr}$ ) of Hemming et al. (1998) are plotted to demonstrate the narrow range of sediment sources for H-layers. It is noteworthy that the $\varepsilon_{\mathrm{Nd}}$ and ${ }^{87} \mathrm{Sr} /{ }^{86} \mathrm{Sr}$ isotopic ratios do not conform to a single mixing relationship between the detritus of Icelandic and H-layers; rather, it requires a much broader range of continental end members (Hemming et al., 1998; Farmer et al., 2003). Our data for $\mathrm{HO}, \mathrm{H} 1$, and $\mathrm{H} 2$ from the Baffin Island cores Hu97-07 and Hu87-09 and Orphan Knoll core Hu91-94 are indistinguishable from those of the central and NE Atlantic cores SU90-09 and V28-82, respectively (Hemming et al., 1998; Grousset et al., 2001). These $\varepsilon_{N d}$ and ${ }^{87} \mathrm{Sr} /{ }^{86} \mathrm{Sr}$ values fall into the range of those from ice-proximal sediments (Barber, 2001; Farmer et al., 2003). In addition, the isotopic ratios of hemipelagic sediments in these slope cores compared well with those of the basal till and proximal glacialmarine deposits in cores of Cumberland Sound (Fig. 7).

The $\varepsilon_{\mathrm{Nd}}$ and ${ }^{87} \mathrm{Sr} /{ }^{86} \mathrm{Sr}$ isotopic ratios from the bottom of $\mathrm{H} 1$ and H2 of core SU90-09 from the central North Atlantic, which were interpreted as the precursor sediments of European ice-sheets, show similarities with those of the ambient pelagic and iceproximal sediments (Fig. 7). Therefore, we suggest that the socalled precursor sediments are in fact the IRD produced by ambient icebergs and do not represent a "specific" iceberg-rafting event (Haapaniemi et al., 2010). Indeed, H-events are characterized by a preceding cooling trend in temperature, which would lead icebergs to survive longer in the ocean. Furthermore, from $\mathrm{H} 2$ to $\mathrm{H} 1$, ice calving was a permanent component of the ice-margin system due to the volume and extent of the different ice sheets, and the WEIS IRD signal would be more likely the signature of D/O cycles (Peck et al., 2007; Haapaniemi et al., 2010).

It is noteworthy that the WEIS displays a more complex dynamics than the LIS. Indeed, while the St. Lawrence Channel and Hudson Strait are fixed outlets throughout the last glacial cycle, some outlets of the WEIS experience a switch from West to North, with the opening of the North Sea after the LGM (Svendsen et al., 2004; Toucanne et al., 2010). The separation between the BIIS and Fennoscandinavian ice-sheet (FIS), as well as the rapid retreat of the Irish Sea ice-stream in this region, induced a sharp drop in the flux of IRD in H1, from the Barra Fan to the Armorican deep-sea fan (Scourse et al., 2009). In that region, icebergs were produced essentially by the FIS and transfer to the Norwegian Sea, which would be traced by an increase in the IRD concentration in that area (Lekens et al., 2009) and a weakening of the signal from the EIS in the mid-Atlantic.

\section{Conclusions}

New centennial to millennial-scale resolution sediment records and re-evaluated earlier data from the Cumberland Sound, Hudson Strait and Trinity Trough provide new insight into the dynamics and instability of the Laurentide ice-sheet for the last $30 \mathrm{ka}$. Cores from the upper slope seaward of Hudson Strait exhibit two IRD peaks separated by a thick, fine-grained, carbonate-rich sediment unit with a typical nepheloid-flow sedimentary structure during $\mathrm{H} 1$ and $\mathrm{H} 2$. In contrast to these cores, two IRD peak signatures in $\mathrm{H} 1$ and $\mathrm{H} 2$ were absent in the SE Baffin Slope core and H-layers are rather dominated by carbonate-rich nepheloid-flow deposit. High density ${ }^{14} \mathrm{C}$-AMS dates allowed us to refine the stratigraphy. Resulting data from the SE Baffin Slope site suggest that the Hudson Strait ice-stream became unstable by ca $1.8 \mathrm{kyr}$ and $1 \mathrm{kyr}$ prior to the deposition of $\mathrm{H} 1$ and $\mathrm{H} 2$ layers, respectively. These new data suggest that the Hudson Strait ice-stream was the first compared to Cumberland Sound to lose stability and was the main supplier of sediments in $\mathrm{H} 1$ and $\mathrm{H} 2$ layers.

At the site proximal to the Hudson Strait ice-stream, IRD peaks were found in both $\mathrm{H} 1$ and $\mathrm{H} 2$ separated by a thick nepheloid-flow deposit. These deposits are as thick as $\sim 4 \mathrm{~m}$ at $1575 \mathrm{~m}$ water depth (Hu97-09; Fig. 3 of Rashid et al., 2003b). Deposition of this unit required large volume of sediments as well as meltwater after the initial deposition of the basal IRD peak. This condition further implies that the ice-sheet did not go back to the "freeze-on" process; rather, it produced an outflow of meltwater that transported a large volume of fine-grained, carbonate-rich sediment from the interior of the LIS. In addition, calving of icebergs operated concurrently with meltwater discharge, as evident from a thin lamination in the IRD layer and randomly oriented IRD in the nepheloid-flow deposit. Our new findings do not support the hypothesis of Alley and MacAyeal (1994) and Alley et al. (2006), who concluded that the ice-sheet went to the freeze-on process after the initial deposition of the basal IRD layer.

New radiogenic isotope $\left(\varepsilon_{\mathrm{Nd}}\right.$ and $\left.{ }^{87} \mathrm{Sr} /{ }^{86} \mathrm{Sr}\right)$ data from northern Hudson Bay, Hudson Strait, and SE Baffin Slope region provide additional constraints for sources of H-layer sediments by fingerprinting the greater Hudson Strait sediment provenance and Labrador Sea background sediments. These data further refine identification of sediment source for $\mathrm{HO}, \mathrm{H} 1$ and $\mathrm{H} 2$. Our $\varepsilon_{\mathrm{Nd}}$ and ${ }^{87} \mathrm{Sr} /{ }^{86} \mathrm{Sr}$ data from $\mathrm{H} 0, \mathrm{H} 1$ and $\mathrm{H} 2$ layers in the Labrador Sea in conjunction with the published $\varepsilon_{\mathrm{Nd}}$ and ${ }^{87} \mathrm{Sr} /{ }^{86} \mathrm{Sr}$ data from the North Atlantic suggest that sediment in these layers primarily originated from Hudson Strait.

Taking into consideration the spatial distribution of IRD peaks and nepheloid-flow deposits from the NE Labrador Sea to the central and eastern North Atlantic Ocean, we put forward a conceptual model of the instability, leads, and lags in various icestreams of the circum-North Atlantic during $\mathrm{H} 1$ and $\mathrm{H} 2$. We hypothesize that the apparent discordance in sequence of IRD in $\mathrm{H} 1$ and H2 layers in the North Atlantic may be due to the geographic differences in core location. We also hypothesize that the instability of the Northern Hemisphere ice-sheets and ice-streams may be better resolved by examining the output of multiple ice-sheets. One of the outstanding issues in this regard is the resolution of zonal and meridional gradients in reservoir ages of surface water (Rashid et al., 2010), especially in the NE Atlantic Ocean during $\mathrm{H} 1$ and $\mathrm{H} 2$, which needs to addressed in future studies (Hall et al., 2011).

\section{Acknowledgements}

This research received support from the Natural Sciences and Engineering Research Council of Canada (NSERC), Fonds pour la Formation de Chercheurs et l'Aide à la Recherche (FCAR), Québec, Canada; and Carbon, Water and Climate (CWC) program of the Ohio State University. We are thankful to Timothy Jull (NSF-AMS Facility of University of Arizona) for providing a few ${ }^{14} \mathrm{C}$-AMS dates. The authors thank Drs. B. MacLean and D.J.W. Piper for their comments which significantly improved the manuscript. Francky Saint-Ange 
was supported by NSERC Visiting Fellowship. The Canadian Coast Guard Scientific (CCGS) Hudson cruise was financed by the Geological Survey of Canada (GSC). K. Best is thanked for carefully reading the initial version of the manuscript.

\section{Appendix A. Supplementary material}

Supplementary data associated with this article can be found, in the online version, at doi:10.1016/j.quascirev.2012.04.026.

\section{References}

Alley, R.B., Dupont, T.K., Parizek, B.R., Anandakrishnan, S., Lawson, D.E., Larson, G.J., Evenson, E.B., 2006. Outburst flooding and the initiation of ice-stream surges in response to climatic cooling: a hypothesis. Geomorphology 75, 76-89.

Alley, R.B., MacAyeal, D.R., 1994. Ice-rafted debris associated with binge/purge oscillations of the Laurentide Ice Sheet. Paleoceanography 9, 503-511.

Alvarez-Solas, J., Charbit, S., Ritz, C., Paillard, D., Ramstein, G., Dumas, C., 2010. Links between ocean temperature and iceberg discharge during Heinrich events. Nature Geoscience 3, 122-126.

Anderson, D.M., 2001. Attenuation of millennial-scale events by bioturbation in marine sediments. Paleoceanography 16, 352-357.

Andrews, J.T., Tedesco, K., Briggs, W.M., Evans, L.W., 1995. A Heinrich-like event, H0 (DC-0): sources for detrital carbonate in the North Atlantic during the Younger Dryas chronozone. Paleoceanography 10, 943-952.

Andrews, J.T., Barber, D.C., 2002. Dansgaard-Oeschger events: is there a signal off the Hudson Strait Ice Stream? Quaternary Science Reviews 21, 443-454.

Andrews, J.T., MacLean, B., 2003. Hudson Strait ice streams: a review of stratigraphy, chronology and links with North Atlantic Heinrich events. Boreas 32, 4-17.

Andrews, J.T., Tedesco, K., 1992. Detrital carbonate-rich sediments, northwestern Labrador Sea: implications for ice-sheet dynamics and iceberg rafting (Heinrich) events in the North Atlantic. Geology 20, 1087-1090.

Auffret, G.A., Boelaert, A., Vergnaud-Grazzini, C., Müller, C., Kerbrat, R., 1996. Identification of Heinrich Layers in core KS 01 North-Eastern Atlantic $\left(46^{\circ} \mathrm{N}\right.$, $\left.17^{\circ} \mathrm{W}\right)$, implications for their origin. Marine Geology 131, 5-20.

Barber, D.C., 2001. Laurentide ice sheet dynamics from 35 to 7 ka: $\mathrm{Sr}-\mathrm{Nd}-\mathrm{Pb}$ isotopic provenance of NW North Atlantic margin sediments, unpub. Ph.D. thesis, University of Colorado, Boulder, CO., p. 142.

Bard, E., Rostek, F., Turon, J.-L., Gendreau, S., 2000. Hydrological impact of Heinrich events in the subtropical northeast Atlantic. Science 289, 1321-1324.

Baas, J.H., Mienert, J., Abrantes, F., Prins, M.A., 1997. Late Quaternary sedimentation on the Portuguese continental margin: climate-related processes and products. Palaeogeography, Palaeoclimatology and Palaeoecology 130, 1-23.

Benway, H.M., McManus, J.F., Oppo, D.W., Cullen, J.L., 2010. Hydrographic changes in the eastern subpolar North Atlantic during the last deglaciation. Quaternary Science Reviews 29, 3336-3345.

Bigg, G.R., Levine, R.C., Green, C.L., 2011. Modelling abrupt glacial North Atlantic freshening: rates of change and their implications for Heinrich events. Global and Planetary Change 79, 176-192.

Bond, G.C., Heinrich, H., Broecker, W.S., Labeyrie, L., Mcmanus, J., Andrews, J. Huon, S., Jantschik, R., Clasen, S., Simet, C., Tedesco, K., Klas, M., Bonani, G., Ivy, S., 1992. Evidence for massive discharges of icebergs into the North Atlantic Ocean during the last glacial period. Nature 360, 245-261.

Bond, G., Showers, W., Elliot, M., Evans, M., Lotti, R., Hajdas, I., Bonani, G., Johnson, S. 1999. The North Atlantic's 1-2 kyr climate rhythm: relation to Heinrich Events, Dansgaard/Oeschger cycles and the Little Ice Age. In: Clark, P.U., Webb, R.S., Keigwin, L.D. (Eds.), Mechanisms of Global Climate Change at Millennial Time Scale. AGU Monograph, vol. 112, pp. 35-58.

Bond, G.C., Showers, W., Cheseby, M., Lotti, R., Almasi, P., deMenocal, P., Priore, P., Cullen, H., Hajdas, I., Bonani, G., 2001. Persistent solar influence on North Atlantic climate during the Holocene. Science 294, 2130-2136.

Bond, G.C., Lotti, R., 1995. Iceberg discharges into the North Atlantic on millennial time scales during the last glaciation. Science 267, 1005-1010.

Bond, G.C., Broecker, W.S., Johnsen, S., McManus, J.F., Labeyrie, L., Jouzel, J., Bonani, G., 1993. Correlations between climate records from North Atlantic sediments and Greenland ice. Nature 365, 143-147.

Bondevik, S., Mangerud, J., Birks, H.H., Gulliksen, S., Reimer, P.J., 2006. Changes in North Atlantic radiocarbon reservoir ages during the Allerod and Younger Dryas. Science 312, 1514-1517.

Brady, E., Otto-Bliesner, B., 2010. The role of meltwater-induced subsurface ocean warming in regulating the Atlantic meridional overturning in glacial climate simulations. Climate Dynamics 36. doi:10.1007/s00382-010-0925-9.

Chapman, M.R., Shackleton, N.J., Duplessy, J.C., 2000. Sea surface temperature variability during the last glacial-interglacial cycle: assessing the magnitude and pattern of climate change in the North Atlantic. Palaeogeography, Palaeoclimatology and Palaeoecology 157, 1-25.

Cheng, J., Liu, Z., He, F., Otto-Bliesner, B., Brady, E., Wehrenberg, M., 2011. Simulated two-stage recovery of Atlantic Meridional Overturning Circulation during last deglaciation. In: Rashid, H., Polyak, L., Mosley-Thompson, E. (Eds.), Understanding the Causes, Mechanisms and Extent of the Abrupt Climate Change. Geophysical Monograph Series, vol. 193, pp. 75-92. Washington, DC.
Clark, P.U., Dyke, A.S., Shakun, J.D., Carlson, A.E., Clark, J., Wohlfarth, B. Mitrovica, J.X., Hostetler, S.W., McCabe, A.M., 2009. The Last Glacial Maximum. Science 325, 710-714.

Clarke, G.K.C., Marshall, S.J., Hillaire-Marcel, C., Bilodeau, G., Veiga-Pires, C., 1999. In: Clark, P.U., Webb, R.S., Keigwin, L.D. (Eds.), Mechanisms of Global Climate Change at Millennial Time Scale, vol. 112. AGU Geophysical Monograph, Washington, D.C, pp. 243-262.

Cortijo, E., Duplessy, J.-C., Labeyrie, L., Duprat, J., Paillard, D., 2005. Heinrich events hydrological impact. Comptes Rendus Geosciences 337, 897-907.

Cortijo, E., Labeyrie, L., Vidal, L., Vautravers, M., Chapman, M., Duplessy, J.C. Elliot, M., Arnold, M., Turon, J.L., Auffret, G., 1997. Changes in sea surface hydrology associated with Heinrich event 4 in the North Atlantic Ocean between $40^{\circ}$ and $60^{\circ} \mathrm{N}$. Earth Planetary Science Letters 146, 29-45.

Dasch, E.J., 1969. Strontium isotopes in weathering profiles, deep-sea sediments, and sedimentary rocks. Geochimica et Cosmochimica Acta 33, 1521-1552.

Dickson, A.J., Austin, W.E.N., Hall, I.R., Maslin, M.A., Kucera, M., 2008. Centennialscale evolution of Dansgaard-Oeschger events in the northeast Atlantic Ocean between 39.5 and 56.5 ka B.P. Paleoceanography 23, PA3206. doi:10.1029/ 2008 PA001595.

Douglas, R.J.W., 1970. Geology and economic minerals of Canada: Geological Survey of Canada, Economic Geology Report no. 1, 838 p.

Dowdeswell, J.A., Elverhoi, A., Andrews, J.T., Hebblen, D., 1999. Asynchroneous deposition of ice-rafted layers in the Nordic seas and North Atlantic Ocean. Nature 400, 348-3351.

Dowdeswell, J.A., Elverhøi, A., 2002. The timing of initiation of fast-flowing ice streams during a glacial cycle inferred from glacimarine sedimentation. Marine Geology 188, 3-14.

Dyke, A.S., Andrews, J.T., Clark, P.U., England, J.H., Miller, G.H., Shaw, J., Veillette, J.J., 2002. The Laurentide and Innuitian ice sheets during the Last Glacial Maximum. Quaternary Science Review 21, 9-31.

Dyke, A.S., Prest, V.K., 1987. Late Wisconsinan and Holocene history of the Laurentide ice sheet. Geographie Physique et Quaternaire 41, 237-264.

Farmer, G.L., Barber, D.C., Andrews, J.T., 2003. Provenance of Late Quaternary iceproximal sediments in the North Atlantic: $\mathrm{Nd}, \mathrm{Sr}$ and $\mathrm{Pb}$ isotopic evidence. Earth and Planetary Science Letters 209, 227-243.

Farmer, G.L., Broxton, D.E., Warren, R.G., Pickthorn, W., 1991. Nd, Sr, and O isotopic variations in metaluminous ash-flow tuffs and related volcanic rocks at the Timber Mountain/Oasis Valley Caldera Complex, SW Nevada: implications for the origin and evolution of large-volume silicic magma bodies. Contribution to Mineralogy and Petrology 109, 53-68.

Faure, G., Hurley, P., Fairbairn, H., 1963. An estimate of the isotopic composition of Strontium in rocks of the Precambrian Shield of North America. Journal of Geophysical Research 68 (8), 2323-2329.

Friedrich, T., Timmermann, A., Timm, O., Mouchet, A., Roche, D.M., 2009. Orbital modulation of millennial-scale climate variability in an earth system model of intermediate complexity. Climate of the Past Discussions 5, 2019-2051.

Grousset, F.E., Cortijo, E., Huon, S., Harvé, L., Richter, T., Burdloff, D., Dupart, J., Weber, O., 2001. Zooming in on Heinrich layer. Paleoceanography 16, 240-259.

Grousset, F.E., Pujol, C., Labeyrie, L., Auffret, G., Boelaert, A., 2000. Were North Atlantic Heinrich events triggered by the behavior of the European ice sheets? Geology 28, 123-126.

Grousset, F.E., Labeyrie, L., Sinko, J.A., Cremer, M., Bond, G., Duprat, J., Cortijo, E. Huon, S., 1993. Patterns of Ice-Rafted Detritus in the Glacial North Atlantic $\left(40-55^{\circ} \mathrm{N}\right)$. Paleoceanography $8,175-192$.

Guihou, A., Pichat, S., Govin, A., Nave, S., Michel, E., Duplessy, J-C., Telouk, P. Labeyrie, L., 2011. Enhanced Atlantic meridional overturning circulation supports the Last Glacial Inception. Quaternary Science Reviews 30 (13-14) 1576-1582.

Haapaniemi, A.I., Scourse, J.D., Peck, V.L., Kennedy, H., Kennedy, P., Hemming, S.R., Furze, M.F.A., PieŃKowski, A.J., Austin, W.E.N., Walden, J., Wadsworth, E., Hall, I.R., 2010. Source, timing, frequency and flux of ice-rafted detritus to the Northeast Atlantic margin, 30-12 ka: testing the Heinrich precursor hypothesis. Boreas 39, 576-591.

Hall, I.R., Colmenero-Hidalgo, E., Zahn, R., Peck, V.L., Hemming, S.R., 2011. Centennial to millennial-scale ice-ocean interactions in the subpolar Northeast Atlantic 18 to 41 ka ago. Paleoceanography. doi:10.1029/2010pa002084.

Hall, F.R., Andrews, J.T., Jennings, A., Vilks, G., Moran, K., 1999. Late Quaternary sediments and chronology of the northeast Labrador shelf (Karlsefni Trough, Saglek Bank): links to glacial history. Geological Society of America Bulletin 111, 1700-1713.

Henrich, R., Kassens, H., Vogelsang, E., Thiede, J., 1989. Sedimentary facies of glacialinterglacial cycles in the Norwegian Sea during the last 350 ka. Marine Geology 86, 283-319.

Heinrich, H., 1988. Origin and consequences of cyclic ice rafting in the northeast Atlantic Ocean during the past 130,000 years. Quaternary Research $29,143-152$.

Hemming, S.R., Broecker, W.S., Sharp, W.D., Bond, G.C., Gwiazda, R.H., McManus, J.F. Klas, M., Hajdas, I., 1998. Provenance of Heinrich layers in core V28-82, northeastern Atlantic: ${ }^{40} \mathrm{Ar} /{ }^{39} \mathrm{Ar}$ ages of ice-rafted hornblende, $\mathrm{Pb}$ isotopes in feldspar grains, and $\mathrm{Nd}-\mathrm{Sr}-\mathrm{Pb}$ isotopes in the fine sediment fraction. Earth and Planetary Science Letters 164, 317-333.

Hesse, R., Khodabakhsh, S., 1998. Depositional facies of late Pleistocene Heinrich events in the Labrador Sea. Geology 26, 103-106.

Hesse, R., Rashid, H., Khodabakhsh, S., 2004. Fine-grained sediment lofting from meltwater-generated turbidity currents during Heinrich events. Geology 32, 449-452. 
Hillaire-Marcel, C., de Vernal, A., Piper, D.J.W., 2007. Lake Agassiz final drainage event in the northwest North Atlantic. Geophysical Research Letters 34. doi:10.1029/2007GL030396.

Hillaire-Marcel, C., de Vernal, A., Bilodeau, G., 1994. Isotope stratigraphy, sedimentation rates, deep circulation, and carbonate vent in the Labrador Sea during the last $200 \mathrm{kyr}$. Canadian Journal of Earth Sciences 31, 63-89.

Hodell, D.A., Curtis, J.H., 2008. Oxygen and carbon isotopes of detrital carbonate in North Atlantic Heinrich Events. Marine Geology 256, 30-35.

Hulbe, C.L., MacAyeal, D.R., Denton, G.H., Kleman, J., Lowell, T.V., 2004. Catastrophic ice shelf breakup as the source of Heinrich event icebergs. Paleoceanography 19, PA1004.

Huppertz, T.J., Piper, D.J.W., 2009. The influence of shelf-crossing glaciation on continental slope sedimentation, Flemish Pass, eastern Canadian continental margin. Marine Geology 265, 67-85.

Jennings, A.E., Tedesco, K.A., Andrews, J.T., Kirby, M.E., 1996. Shelf erosion and glacial ice proximity in the Labrador Sea during and after Heinrich events $(\mathrm{H}-3$ or 4 to $\mathrm{H}-0$ ) as shown by foraminifera. In: Andrews, et al. (Eds.), Late Quaternary Paleoceanography of the North Atlantic Margins. Geo. Soc. Sp. Pub, vol. 111, pp. 29-49.

Jennings, A.E., 1993. The Quaternary history of Cumberland Sound, southeastern Baffin Island: the marine evidence. Géographie physique et Quaternaire 47, 21-42.

Josenhans, H.W., Zevenhuizen, J., Klassen, R.A., 1986. The Quaternary geology of the Labrador Shelf. Canadian Journal of Earth Sciences 23, 1190-1213.

Jullien, E., Grousset, F.E., Hemming, S.R., Peck, V.L., Hall, I.R., Jeantet, C., Billy, I., 2006 Contrasting conditions preceding MIS3 and MIS2 Heinrich events. Global and Planetary Change 54, 225-238.

Kageyama, M., Mignot, J., Swingedouw, D., Marzin, C., Alkama, R., Marti, O., 2009 Glacial climate sensitivity to different states of the Atlantic Meridional Overturning Circulation: results from the IPSL model. Climate of the Past Discussions $5,551-570$.

Khodabakhsh, S., 1997. Pleistocene Laurentide Ice Sheet drainage into the Labrador Sea: sedimentary facies, depositional mechanisms, stratigraphy and significance of Heinrich events, Unpubl.. Ph.D. thesis, McGill University, Montréal, Québec, pp. 266

Knutz, P.C., Zahn, R., Hall, I.R., 2007. Centennial-scale variability of the British Ice Sheet: implications for climate forcing and Atlantic meridional overturning circulation during the last deglaciation. Paleoceanography 22, PA1207. doi:10.1029/2006PA001298

Lebreiro, S.M., Moreno, J.C., McCave, I.N., Weaver, P.P.E., 1996. Evidence for Heinrich layers off Portugal (Tore Seamount: $39^{\circ} \mathrm{N}, 12^{\circ} \mathrm{W}$ ) Marine Geology 131, 47-56.

Lekens, W.A.H., Sejrup, H.P., Haflidason, H., PetersenØ., G., Hjelstuen, B., Knorr, G., 2005. Laminated sediments preceding Heinrich event 1 in the Northern North Sea and Southern Norwegian Sea: origin, processes and regional linkage. Marine Geology 216, 27-50.

Lekens, W.A.H., Haflidason, H., Sejrup, H.P., Nygard, A., Richter, T., Vogt, C., Frederichs, T., 2009. Sedimentation history of the northern North Sea Margin during the last $150 \mathrm{ka}$. Quaternary Science Reviews 28, 469-483.

Lewis, C.F.M., Miller, A.A., Levac, L.E., Piper, D.J.W., Sonnichsen, G.V., 2012. Lake Agassiz outburst age and routing by Labrador Current and the 8.2 cal ka cold event. Quaternary International 260, 83-97.

Liu, Z., Otto-Bliesner, B.L., He, F., Brady, E.C., Tomas, R., Clark, P.U., Carlson, A.E., Lynch-Stieglitz, J., Curry, W., Brook, E., Erickson, D., Jacob, R., Kutzbach, J. Cheng, J., 2009. Transient simulation of last deglaciation with a new mechanism for Bolling-Allerod warming. Science 325, 310-314.

Lynch-Stieglitz, J., Adkins, J.F., Curry, W.B., Dokken, T., Hall, I.R., Herguera, J.C. Hirschi, J.J.-M., Ivanova, E.V., Kissel, C., Marchal, O., Marchitto, T.M., McCave, I.N. McManus, J.F., Mulitza, S., Ninnemann, U., Peeters, F., Yu, E.-F., Zahn, R., 2007. Atlantic meridional overturning circulation during the Last Glacial Maximum. Science 316, 66-69.

Maclean, B., Williams, A., Jennings, A.E., Blakeney, C., 1986. Bedrock and surficial geology of Cumberland Sound, N.W.T. Current Research, Part B, Geological Survey of Canada 86-1B, 605-615

Maclean, B., 1985. Geology of the Baffin Island Shelf, Quaternary environments. In: Andrews, J.T. (Ed.), Eastern Canadian Arctic, Baffin Bay, and Western Greenland. Allen and Unwin, Boston, pp. 154-177.

Marcott, S.A., Clark, P.U., Padman, L., Klinkhammer, G.P., Springer, S.R., Liu, Z., OttoBliesner, B.L., Carlson, A.E., Ungerer, A., Padman, J., He, F., Cheng, J., Schmittner, A., 2011. Ice-shelf collapse from subsurface warming as a trigger for Heinrich events. Proceedings of the National Academy of Sciences of the United States of America 108, 13415-13419.

McManus, J.F., Anderson, R.F., Broecker, W.S., Fleisher, M.Q., Higgins, S.M., 1998 Radiometrically determined sedimentary fluxes in the sub-polar North Atlantic during the last 140,000 years. Earth and Planetary Science Letters 155, 29-43.

McNeely, R., Dyke, A.S., Southon, J.R., 2006. Canadian Marine Reservoir Ages, Preliminary Data Assessment. Geological Survey of Canada. p.3 (Open File 5049).

Peck, V.L., Hall, I.R., Zahn, R., Elderfield, H., 2008. Millennial-scale surface an subsurface paleothermometry from the northeast Atlantic, 55-8ka BP. Paleoceanography 23. doi:10.1029/2008PA001631.

Peck, V.L., Hall, I.R., Zahn, R., Grousset, F., Hemming, S.R., Scourse, J.D., 2007. The relationship of Heinrich events and their European precursors over the past 60 ka BP: a multi-proxy ice-rafted debris provenance study in the North East Atlantic. Quaternary Science Reviews 26, 862-875.
Peltier, W.R., 2004. Global glacial isostasy and the surface of the Ice-Age Earth: the ICE-5G (VM2) model and GRACE. Annual Review of Earth and Planetary Sciences 32, 111-149.

Piper, D.J.W., de Wolfe, M., 2003. Petrographic evidence from the eastern Canadian margin of shelf crossing glaciations. Quaternary International 99-100, 99-113.

Pflaumann, U., Sarnthein, M., Chapman, M., d'Abreu, L, Funnell, B., Huels, M. Kiefer, T., Maslin, M., Schulz, H., Swallow, J., van Kreveld, S., Vautravers, M., Vogelsang, E., Weinelt, M., 2003. Glacial north Atlantic: sea-surface conditions reconstructed by GLAMAP 2000. Paleoceanography 18, 1065. doi:10.1029/ 2002 pa000774.

Rahmstorf, S., 1994. Rapid climate transitions in a coupled ocean-atmosphere model. Nature 372, 82-85.

Rashid, H., Piper, D.J.W., Flower, B.P., 2011. The role of Hudson Strait outlet in Younger Dryas sedimentation in the Labrador Sea. In: Rashid, H., Polyak, L., Mosley-Thompson, E. (Eds.), Abrupt Climate Change: Mechanisms, Patterns, and Impacts. AGU Geophysical Monograph Series, vol. 193, pp. 93-110. Washington, DC.

Rashid, H., Vouis, R., Boyle, E.A., Skinner, L.C., 2010. Revised reconstruction of the North Atlantic meridional overturning circulation during the last deglaciation: a multi-proxy study, AGU Fall Meeting, Abstract \# GC23H-03.

Rashid, H., Boyle, E.A., 2008. Response to comment "mixed layer deepening during Heinrich Events: a multi-planktonic foraminiferal $\delta^{18} \mathrm{O}$ approach". Science 320. $1161 \mathrm{~b}$

Rashid, H., Piper, D.J.W., 2007. The extent of ice on the continental shelf off Hudson Strait during Heinrich Events 1-3. Canadian Journal of Earth Sciences 44, 1537-1549.

Rashid, H., Hesse, R., Piper, D.J.W., 2003a. Origin of unusually thick ice-proximal Heinrich layers $\mathrm{H}-1$ to $\mathrm{H}-3$ in the northwest Labrador Sea. Earth Planetary Science Letters 208, 319-336.

Rashid, H., Hesse, R., Piper, D.J.W., 2003b. Distribution, thickness and origin and Heinrich layer 3 in the Labrador Sea. Earth Planetary Science Letters 205, 281-293.

Rashid, H., 2002. The deep-sea record of rapid Late Pleistocene paleoclimate change and ice-sheet dynamic from the Labrador Sea sediments, Ph.D. thesis, McGill University, Montréal, Québec, Canada.

Reimer, P.J., Baillie, MG.L., Bard, E., Bayliss, A., Beck, J.W., Blackwell, P.G., Bronk Ramsey, C., Buck, C.E., Burr, G.S., Edwards, R.L., Friedrich, M., Grootes, P.M., Guilderson, T.P., Hajdas, I., Heaton, T.J., Hogg, A.G., Hughen, K.A., Kaiser, K.F., Kromer, B., McCormac, F.G., Manning, S.W., Reimer, R.W., Richards, D.A., Southon, J.R., Talamo, S., Turney, C.S.M., van der Plicht, J., Weyhenmeyer, C.E., 2009. IntCal09 and Marine09 radiocarbon age calibration curves, $0-50,000$ years cal BP. Radiocarbon 51 (4), 1111-1150.

Renold, M., Raible, C.C., Yoshimori, M., Stocker, T.F., 2010. Simulated resumption of the North Atlantic meridional overturning circulation-slow basin-wide advection and abrupt local convection. Quaternary Science Reviews 29, 101-112.

Ruddiman, W.F., 1977. Late Quaternary deposition of ice-rafted sand in the subpolar North Atlantic $\left(40-65^{\circ} \mathrm{N}\right)$. Geological Society of America Bulletin 88, 1813-1827.

Scourse, J.D., Haapaniemi, A.I., Colmenero-Hidalgo, E., Peck, V.L., Hall, I.R., Austin, W.E.N., Knutz, P.C., Zahn, R., 2009. Growth, dynamics and deglaciation of the last British-Irish ice sheet: the deep-sea ice-rafted detritus record. Quaternary Science Reviews 28, 3066-3084.

Scourse, J.D., Hall, I.R., McCave, I.N., Young, J.R., Sugdon, C., 2000. The origin of Heinrich layers: evidence from $\mathrm{H} 2$ for European precursor events. Earth and Planetary Science Letters 182, 187-195.

Seidov, D., Haupt, B.J., 2003. Freshwater teleconnections and ocean thermohaline circulation. Geophysical Research Letters 30, 1329. doi:10.1029/2002GL016564.

Sejrup, H.P., Hjelstuen, B.O., Torbjørn Dahlgren, K.I., Haflidason, H., Kuijpers, A. Nygård, A., Praeg, D., Stoker, M.S., Vorren, T.O., 2005. Pleistocene glacial history of the NW European continental margin. Marine and Petroleum Geology 22, 1111-1129.

Shaw, J., Piper, D.J.W., Fader, G.B.J., King, E.L., Todd, B.J., Bell, T., Batterson, M.J., Liverman, D.G.E., 2006. A conceptual model of the deglaciation of Atlantic Canada. Quaternary Science Reviews 25, 2059-2081.

Stanford, J.D., Rohling, E.J., Bacon, S., Roberts, A.P., Grousset, F.E., Bolshaw, M., 2011 A new concept for the paleoceanographic evolution of Heinrich event 1 in the North Atlantic. Quaternary Science Reviews 30, 1047-1066.

Stanford, J.D., Rohling, E.J., Hunter, S.E., Roberts, A.P., Rasmussen, S.O., Bard, E., McManus, J.F., Fairbanks, R.G., 2006. Timing of meltwater pulse 1a and climate responses to meltwater injections. Paleoceanography 21. doi:10.1029/ 2006 pa001340.

Stein, R., Hefter, J., Grützner, J., Voelker, A., Naafs, B.D.A., 2009. Variability of surface water characteristics and Heinrich-like events in the Pleistocene midlatitude North Atlantic Ocean: biomarker and XRD records from IODP Site U1313 (MIS 16-9). Paleoceanography 24. doi:10.1029/2008PA001639.

Stevenson, R.K., Meng, X.W., Hillaire-Marcel, C., 2008. Impact of melting of the Laurentide Ice Sheet on sediments from the upper continental slope off southeastern Canada: evidence from $\mathrm{Sm}-\mathrm{Nd}$ isotopes. Canadian Journal of Earth Sciences 45, 1243-1252.

Stoner, J.S., Channell, J.E.T., Hillaire-Marcel, C., 1998. A 200 ka geomagnetic chronostratigraphy for the Labrador Sea: indirect correlation of the sediment record to SPECMAP. Earth and Planetary Science Letters 159, 165-181.

Stouffer, R.J., Yin, J., Gregory, J.M., Dixon, K.W., Spelman, M.J., Hurlin, W., Weaver, A.J., Eby, M., Flato, G.M., Hasumi, H., Hu, A., Jungclaus, J.H., Kamenkovich, I.V., Levermann, A., Montoya, M., Murakami, S., Nawrath, S., 
Oka, A., Peltier, W.R., Robitaille, D.Y., Sokolov, A., Vettoretti, G., Weber, S.L., 2006. Investigating the causes of the response of the thermohaline circulation to past and future climate changes. Journal of Climate 19, 1365-1387.

Stuiver, M., Braziunas, T.F., 1993. Modeling atmospheric $14 \mathrm{C}$ influences and ${ }^{14} \mathrm{C}$ ages of marine samples to 10,000 BC. Radiocarbon 35, 137-189.

Svendsen, J.I., 29 others, 2004. Late Quaternary ice sheet history of northern Eurasia. Quaternary Science Reviews 23, 1229-1271.

Thomas, F.C., Hardy, I.A., Rashid, H., 2003. Bryozoan-rich layers in surficial Labrador Slope sediments, eastern Canadian Arctic. Canadian Journal of Earth Sciences 40, 337-350.

Timmermann, A., Menviel, L., 2009. What drives the climate flip-flops? Science 325 , 273-274.

Trauth, M.H., Sarnthein, M., Arnold, M., 1997. Bioturbational mixing depth and carbon flux at the seafloor. Paleoceanography 12, 517-526.

Toucanne, S., Zaragosi, S., Bourillet, J.-F., Marieu, V., Cremer, M., Kageyama, M., Van Vliet-Lanoë, B., Eynaud, F., Turon, J.-L., Gibbard, P.L., 2010. The first estimation of Fleuve Manche palaeoriver discharge during the last deglaciation: evidence for Fennoscandian ice sheet meltwater flow in the English Channel ca 20-18 ka ago. Earth and Planetary Science Letters 290, 459-473.

Toucanne, S., Zaragosi, S., Bourillet, J.F., Cremer, M., Eynaud, F., Van Vliet-Lanoë, B., Penaud, A., Fontanier, C., Turon, J.L., Cortijo, E., Gibbard, P.L., 2009. Timing of massive 'Fleuve Manche' discharges over the last 350 kyr: insights into the European ice-sheet oscillations and the European drainage network from MIS 10 to 2 . Quaternary Science Reviews 28, 1238-1256.
Veiga-Pires, C.C., Hillaire-Marcel, C., 1999. U and Th isotopic constraints on the duration of Heinrich events $\mathrm{HO}-\mathrm{H} 4$ in the southeastern Labrador Sea. Paleoceanography $14,187-199$.

Verplanck, E.P., Farmer, G.L., Andrews, J., Dunhill, G., Millo, C., 2009. Provenance of Quaternary glacial and glacimarine sediments along the southeast Greenland margin. Earth and Planetary Science Letters 286, 52-62.

Waelbroeck, C., Duplessy, J.-C., Michel, E., Labeyrie, L., Paillard, D., Duprat, J., 2001 The timing of the last deglaciation in North Atlantic climate records. Nature 412 $724-727$.

Wang, D., Hesse, R., 1996. Continental slope sedimentation adjacent to an ice margin. II. Glaciomarine depositional facies on Labrador Slope and glacial cycles. Marine Geology 135, 65-96.

Wasserburg, G.J., Jacousen, S.B., DePaolo, D.J., McCulloch, M.T., Wen, T., 1981. Precise determination of SmNd ratios, Sm and Nd isotopic abundances in standard solutions. Geochimica et Cosmochimica Acta 45, 2311-2323.

Watkins, S.J., Maher, B.A., Bigg, G.R., 2007. Ocean circulation at the Last Glacial Maximum: a combined modeling and magnetic proxy-based study. Paleoceanography 22, PA2204. doi:10.1029/2006PA001281.

Wu, G., Hillaire-Marcel, C., 1994. Oxygen isotope compositions of sinistral Neogloboquadrina pachyderma tests in surface sediments: North Atlantic Ocean. Geochimica et Cosmochimica Acta 58, 1303-1312.

Zaragosi, S., Eynaud, F., Pujol, C., Auffret, G.A., Turon, J.-L., Garlan, T., 2001. Initiation of the European deglaciation as recorded in the northwestern Bay of Biscay slope environments (Meriadzek Terrace and Trevelyan Eascarpment): a multiproxy approach. Earth Planetary Science Letters 188, 493-507. 